\title{
Esculpir a vida com palavras: \\ Autobiografia de Marina Núñez del Prado (1908-1995)
}

Giovanna Pezzuol Mazza ${ }^{1}$

Resumo: Marina Núñez del Prado (1908-1995), escultora boliviana, iniciou seus estudos na Academia Nacional de Bellas Artes de La Paz, na qual se tornou a primeira professora, em 1930. Paulatinamente, obteve reconhecimento no circuito artístico internacional, com destaque para sua participação na $26^{\mathrm{a}}$ edição da Bienalle di Venezia, em 1952. Participou ativamente do movimento indigenista andino em sua vertente artística, e grande parte de sua produção busca representar aspectos das tradições indígenas bolivianas. Em suas obras, optou por centrar suas atenções na representação da mulher indígena, principal eixo condutor de seu trabalho. Este artigo tem como objetivo discutir questões levantadas a partir da análise de sua autobiografia, intitulada Eternidad en los Andes e publicada em 1973, na qual se destacam os principais marcos de seu desenvolvimento artístico e profissional. Além disso, esse documento contém uma série de fotografias, selecionadas pela própria artista, que estabelecem paralelos interessantes com o texto elaborado, e que serão parcialmente analisadas.

Palavras-chave: Marina Núñez del Prado; Eternidad en los Andes; autobiografia.

\section{Sculpt life with words: Autobiography of Marina Núñez del Prado (1908-1995)}

\begin{abstract}
Marina Núñez del Prado (1908-1995), a Bolivian sculptress, began her studies at the National Academy of Fine Arts in La Paz, where she became the first female teacher in 1930. Gradually, she gained recognition in the international artistic circuit, with emphasis on her participation in the XXVI Bienalle di Venezia in 1952. She participated actively in the Andean Indian movement in its artistic field, and much of her production seeks to represent aspects of the indigenous Bolivian traditions. In her work, she chose to focus attention on the representation of indigenous women, the main axis of her work. This article aims to discuss issues raised from the analysis of his autobiography, entitled Eternidad en los Andes and published in 1973, which highlights the main milestones of her artistic and professional development. In addition, this document contains a series of photographs, selected by the artist herself, which establish interesting parallels with the prepared text, which will be partially analyzed.
\end{abstract}

Keyword: Marina Núñez del Prado; Eternidad en los Andes; autobiography.

\footnotetext{
${ }^{1}$ Mestra pelo Programa em História Social da Universidade de São Paulo (USP), Brasil. Pesquisa sob o título Esculpindo a mulher indígena: produção artística e autobiográfica de Marina Núñez del Prado (1908-1995), financiada pelo Conselho Nacional de Desenvolvimento Científico e Tecnológico (CNPq). Endereço para correspondência: Av. Professor Lineu Prestes, 338- Butantã, São Paulo/ SP, CEP: 05508000. E-mail: gipezzuol@gmail.com
}

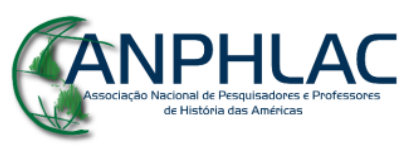

Revista Eletrônica da ANPHLAC, ISSN 1679-1061, №. 24, p. 155-188, Jan./Jun., 2018.

http://revista.anphlac.org.br 
Artigo recebido em: 21/09/2017

Artigo aprovado para publicação em: 11/03/2018

\section{Introdução}

A artista boliviana Marina Núñez del Prado nasceu em 1908, na cidade de La Paz, e cresceu em meio à elite local. Filha de Sara Viscarra e de Guillermo Núñez del Prado, ambos de descendência espanhola, viveu sua infância e parte da juventude no bairro nobre de Sopocachi, em companhia de seus quatro irmãos: Guillermo, Eduardo, Nilda e Luis. Descendente de José Núñez del Prado - importante engenheiro do século XIX que participou de diversas construções públicas, como da catedral, do teatro municipal e do Palácio do Governo da cidade de La Paz - teria herdado do bisavô, segundo suas próprias palavras, a "inclinação pelas belas artes” (DEL PRADO, 1973, p. 1). Ainda segundo sua descrição, seu pai, por sua vez, teria dominado as técnicas da pintura, do desenho e da música, além de possuir um talento especial para a jardinagem. Ainda assim, optou por dedicar-se profissionalmente à carreira militar, tendo alcançando o posto de general da brigada. Sua mãe, apresentada em sua autobiografia como "a personificação do otimismo e da tenacidade para realizar o que se propunha" (DEL PRADO, 1973, p. 3), permaneceu grande parte da vida em casa, responsável pelos afazeres domésticos e pela criação de seus cinco filhos.

Desde a infância, Núñez del Prado esteve próxima a diversas linguagens artísticas como a música, a pintura e a escultura, recebendo aulas particulares em sua casa. Entre os anos de 1927 e 1929, estudou no Conservatorio Nacional de Música e na Academia Nacional de Bellas Artes de La Paz e, em 1930, foi a primeira mulher aprovada em concurso para lecionar na instituição, dando aulas de "Escultura" e "Anatomia Artística". Depois de uma experiência de dois anos em Buenos Aires, na qual expôs suas esculturas em diversos museus e galerias pelo país, a artista recebeu, em 1940, uma bolsa para estudar na Art Students League, e mudou-se para Nova York. Com um ateliê instalado, permaneceu na cidade por nove anos travando contato direto com artistas e intelectuais pertencentes às vanguardas da época. Em 1951, Núñez del

\section{CANPHLAC}


Prado expôs na $1^{\mathrm{a}}$ Bienal do Museu de Arte Moderna de São Paulo ${ }^{2}$ e no Museu Nacional de Arte no Rio de Janeiro. Em 1952, recebeu um convite para expor vinte e quatro esculturas na $26^{\mathbf{a}}$ edição da Biennale di Venezia, representando a Bolívia pela primeira vez na mostra. Ao final de sua passagem pela Europa, em 1953, expôs suas obras no Petit Palais, em Paris. Tendo acumulado uma série de prêmios ao longo da vida, sua carreira foi paulatinamente se consolidando na Bolívia e, posteriormente, em âmbito internacional.

Depois de sua passagem pelos Estados Unidos, a artista regressou à Bolívia em 1949 e, cinco anos mais tarde, abriu sua casa em La Paz para uma exposição permanente de suas obras. Após casar-se, aos 64 anos, com o escritor peruano Jorge Falcón Gárfias, mudou-se, em 1972, para a cidade de Lima, no Peru, onde permaneceu até o final de sua vida. Atualmente, grande parte de sua obra encontra-se dividida entre duas fundações que levam o nome de sua família, Núñez del Prado, nas capitais La Paz e Lima. Em 1994, sua obra foi declarada Tesouro Artístico e Cultural da Nação pelo governo boliviano e, no ano de 2006, a data de seu aniversário tornou-se Dia das Artes Plásticas.

Desde a década de 1950, Marina Núñez del Prado dedicou grande quantidade de tempo e recursos para perpetuar sua memória e seu legado artístico, tomando as rédeas de seu processo de reconhecimento como artista de prestígio. A partir da segunda metade do século XX, atuou ativamente em três principais frentes: a abertura de suas duas fundações, respectivamente em La Paz e Lima, responsáveis pela administração de duas casa-museus; a organização de seu acervo pessoal, de cartas, fotografias, álbuns, notícias de revistas e jornais, dentre outros documentos, atualmente conservados pela fundação de Lima; e, finalmente, a publicação de sua autobiografia intitulada Eternidad en los Andes.

Para o presente artigo, pretende-se discutir algumas questões levantadas a partir da análise da autobiografia da artista. Em termos gerais, o documento lançou luz sob muitos aspectos da trajetória de Núñez del Prado, sobretudo no que tange a seu desenvolvimento como escultora e sua atuação no mundo profissional. Como veremos, muitos dados de sua biografia, sobretudo relacionados à esfera pessoal, não puderam ser

2 A artista participou da mostra com as esculturas Pachamama, Amauta e Com a vida nos ombros. In: Catálogo da I Bienal do Museu de Arte Moderna de São Paulo. São Paulo, 1951. Posteriormente, participou também da II e $3^{\text {a }}$ Bienal do Museu de Arte Moderna de São Paulo e da $8^{a}$ Bienal de São Paulo.

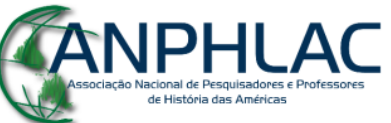

Revista Eletrônica da ANPHLAC, ISSN 1679-1061, №. 24, p. 155-188, Jan./Jun., 2018.

http://revista.anphlac.org.br 
reconstruídos. Por essa razão, parte-se da premissa de que a artista optou por arquitetar sua imagem pública como uma profissional do campo artístico, deixando em segundo plano aspectos de sua vida pessoal e afetiva. Além disso, diversas publicações em jornais, revistas e livros, especialmente na Bolívia, seguiram a narrativa que ela própria elaborou em sua autobiografia. Dessa forma, cabe afirmar que a artista logrou perpetuar sua história através de suas próprias considerações, apagando em grande medida possíveis contradições e desentendimentos em sua carreira.

Outro aspecto interessante do documento diz respeito ao grande número de imagens e fotografias selecionadas pela própria artista, organizadas de modo a estabelecerem paralelos e associações com o texto elaborado. Com o objetivo de garantir uma visão ampla acerca dessa publicação, parte das imagens será analisada. Considerando-se sua atuação como artista visual, é notável a forma como ela construiu uma narrativa não apenas textual, mas também imagética, acerca de sua trajetória.

Antes de iniciar a reflexão, vale destacar alguns apontamentos de caráter metodológico. Tal como esmiuçado por Pierre Nora (1993, p. 7-28), o enfrentamento entre os conceitos de história e memória é de grande valia para compreender algumas nuances dos documentos autobiográficos. De modo geral, estes seriam pautados em grande medida pela memória de seus narradores; porém, com o objetivo de se constituir como história oficial dos mesmos. Para Nora, a memória seria um fenômeno permanentemente vivo e, portanto, em constante transformação, vinculada ao tempo presente, enquanto a história, por sua vez, seria inevitavelmente uma reconstrução incompleta do passado.

Ao descrever a memória, Ecléa Bosi, por sua vez, indica que esta seria um "cabedal infinito do qual só registramos um fragmento" (BOSI, 2009, p. 39). Segundo a autora, para analisar a memória de sujeitos determinados, é fundamental lembrarmos que os mesmos intervêm nessas lembranças, que não são, portanto, completas e lineares, mas reconstruídas constantemente conforme os interesses em questão e, portanto, voltadas ao presente. Nesse sentido, o ato de lembrar seria uma espécie de "trabalho", não necessariamente natural, mas intencional, por conta da impossibilidade de olharmos para o passado tal como este foi vivido e experienciado.

Ao se debruçar sobre as práticas autobiográficas de Patrícia Galvão e Antonieta Rivas Mercado, Romilda Costa Motta ressalta que o ato de trazer uma lembrança à tona

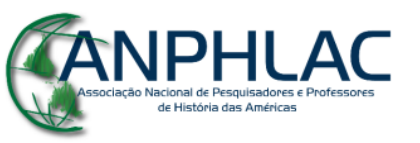


significa necessariamente uma "reatualização do vivido": "Logo, nessas tentativas de ordenação das imagens do passado, o que é engendrado são representações e imagens do passado, não coincidindo, ipsis litteris, com a experiência primeira, vivida" (MOTTA, 2015, p. 57). Ao trabalhar com documentos vinculados à memória de Marina Núñez del Prado, portanto, buscou-se tomar o devido cuidado para não interpretá-los como dados objetivos do passado, mas como construções com propósitos específicos.

\section{Eternidad en los Andes}

Al escribir estas Memorias, siento que llega la hora de decir muchas de éstas cosas que se van acumulando en los rincones del alma. Al expresarlas en forma pública, me parece que se ejecuta una labor de profilaxia espiritual. (DEL PRADO, 1973, p. 89)

Em 1973, Marina Núñez del Prado publicou sua autobiografia, intitulada Eternidad en los Andes, pela editora chilena Lord Cochrane ${ }^{3}$, com tiragem de 3.000 exemplares. O livro contém 227 páginas escritas e 217 dedicadas a reproduções de fotografias e obras da artista, e está dividido em 91 itens, cada qual correspondente a oito grupos temáticos: família; formação artística e viagem à Buenos Aires; Estados Unidos; retorno à Bolívia; viagens pela América Latina; viagens pela Europa; viagens pelo Oriente Médio e Fundación Núñez del Prado de La Paz.

O primeiro dado a ser observado diz respeito à amplitude de frentes que esse documento autobiográfico procura dar conta. Para além de relatar sua trajetória de vida, a artista constrói um grande arcabouço de imagens que acompanham o texto, e que serão analisadas mais adiante. Além disso, ela realiza um verdadeiro esforço bibliográfico, elencando cuidadosamente, ao final do documento, seus dados biográficos, as exposições que realizou, obras de sua autoria em museus e coleções particulares e comentários sobre sua obra em livros, revistas e jornais.

Nesse sentido, a artista esteve muito atenta tanto às repercussões de sua obra -

3 Infelizmente, não foram encontradas fontes sobre o porquê da publicação de sua autobiografia por uma editora chilena, e não boliviana ou peruana. Porém, em uma nota solta deixada pela artista em seus arquivos, provavelmente o rascunho de uma carta cujo destinatário é desconhecido, ela afirma que teria obtido ajuda de Pablo Neruda para a publicação da autobiografia. Naquele momento, sua irmã Nilda vivia no Chile, e era relativamente próxima ao poeta, que inclusive a dedicou um de seus poemas. Outra possibilidade teria sido a interferência de Gabriela Mistral, amiga próxima e muito influente nos círculos chilenos.

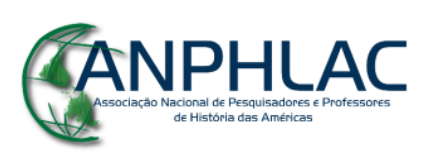

Revista Eletrônica da ANPHLAC, ISSN 1679-1061, №. 24, p. 155-188, Jan./Jun., 2018.

http://revista.anphlac.org.br 
acompanhando o que se dizia acerca de sua produção na mídia e nos veículos impressos em geral - quanto por quais espaços suas peças circulavam. Ao enumerar publicações de origens diversas focadas em certos aspectos de sua atuação, é provável que ela tivesse a intenção de induzir seus leitores para determinadas interpretações, apagando conscientemente contradições e opiniões mais críticas. Tal como indica Philippe Artières, este seria o cerne de toda composição autobiográfica. O autor destaca o caráter narrativo desse suporte, através do qual seria possível escolher e classificar certos acontecimentos como centrais em detrimento de outros, conforme o sentido que o autor procura elucidar sobre sua vida. Por essa razão, Artières (1998, p. 9-34) defende que esta seria a prática mais bem acabada de "arquivamento do eu".

Diversos autores já se debruçaram sobre os significados e sentidos dos documentos autobiográficos. De maneira geral, essas práticas são interpretadas como fenômenos ocidentais que provém da antiguidade. Contudo, o termo "autobiografia" estaria ligado à emergência da noção de subjetividade entre os séculos XVIII e XIX no cenário europeu, período no qual "apesar de toda infinidade de diferenças, de lugares, tempo, histórias, economias, identificações culturais, todos os 'eus' passam a ser racionais, agentes e unitários" (SMITH \& WATSON, 1992, p. 7). Sidonie Smith e Julia Watson destacam que, não obstante, a noção de subjetividade configurada naquele contexto estaria direcionada aos homens e, portanto, as mulheres estariam, desde então, distantes da possibilidade de se afirmar plenamente como sujeitos:

Where Western eyes see Man as a unique individual rather than a member of a collectivity, of race or nation, of sex or sexual preference, Western colonized "other" disappears into an anonymous, opaque collectivity of undifferentiated bodies. (SMITH \& WATSON, 1992, p. 7)

Ainda que a escrita autobiográfica tenha como gênese uma concepção masculinizada de indivíduo, ao longo dos séculos, diversas mulheres conseguiram romper essa barreira. Para Smith e Watson, a prática autobiográfica representaria para as mulheres a conquista de uma "subjetividade culturalmente empoderada" (SMITH \& WATSON, 1992, p. 19): "Para a mulher marginalizada, a linguagem autobiográfica serve como uma moeda de troca que compra a entrada na economia social e discursiva" (SMITH \& WATSON, 1992, p. 19).

No âmbito das artes plásticas, uma importante contribuição para o tema é o livro

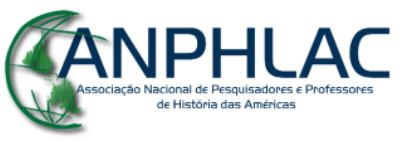


Voicing our Visions - Wrtings by Women's Artists, de Mara R. Witzling, no qual a autora faz um levantamento de importantes mulheres artistas que mantiveram uma relação íntima com práticas autobiográficas ao longo de suas vidas. Segundo sua cronologia, a primeira artista a elaborar uma autobiografia teria sido a francesa Élisabeth Vigée Le Brun, no século XIX, a partir de cartas enviadas a sua mecenas, Princesa Kourakin. A partir de então, outras importantes artistas teriam se dedicado a este tipo de escrita, tais como Georgia O’Okeeffe, Frida Kahlo, Remedios Varo, Leonora Carrington, Paula Modersohn-Becker, dentre outras. De modo geral, Witzling esclarece que muitas dessas artistas abordaram em seus textos as contradições entre sua condição de gênero e sua profissão, buscando constantemente responder se poderiam e conseguiriam "ser" artistas. Assim, também evidenciaram sua marginalização no mundo artístico, utilizando-se dessa ferramenta como uma forma de validação de suas profissões:

In part because of women's exclusion from the art world, writings by women artists had special significance to both the artists who wrote and to their readers. Women artists have been isolated, from other artists, from other women artists, from the concept of art itself, and one major reason that they have written has been to validate their functioning as professional artists. (WITZLING, 1991, p. 4)

Como brevemente mencionado, do total de páginas da autobiografia de Marina Núñez del Prado foram identificados oito grupos temáticos distribuídos em quantidades diversas de páginas: família (16); formação artística e viagem à Buenos Aires (27); Estados Unidos (28); retorno à Bolívia (21); viagens pela América Latina (21); viagens pela Europa (56); viagens pelo Oriente Médio (8) e Fundación Núñez del Prado de La Paz (6). A partir desses dados, fica evidente que apenas uma pequena porcentagem concentra-se em temas familiares, somando apenas 16 páginas. Evidentemente, menções breves acerca de eventos ou acontecimentos importantes com membros da família Núñez del Prado aparecem no decorrer dos outros itens. Porém, estes nunca se apresentam como centrais, e geralmente são apresentados apenas para esclarecer algum outro aspecto objetivo. Nesse sentido, a artista não estava preocupada em reconstruir sua narrativa familiar. Além disso, ela praticamente não menciona aspectos de sua vida afetiva, sendo bem cuidadosa em relatar apenas encontros com colegas com os quais

\section{CANPHLAC}


também trocava nos níveis artístico e intelectual. Como um exemplo marcante dessa escolha, a artista não menciona o próprio casamento com Jorge Falcón Gárfias.

Ao analisar as autobiografias selecionadas em seu livro, Witzling ressalta que as mulheres artistas, pelo desejo de construírem uma imagem pública como artistas bem sucedidas, muitas vezes suprimiram desses documentos autobiográficos aspectos de sua existência considerados "inapropriados". Nessa categoria, poderiam incluir-se relatos demasiadamente familiares e de foro íntimo, assim como passagens mais carregadas em termos emocionais e sentimentos intensos, como "de ódio, amor, medo, divulgação de encontros sexuais explícitos ou o detalhamento de experiências psicológicas dolorosas" (JELINECK, 1980, s/p). Pelo fato da "narrativa do artista bem sucedido" ser naturalizada como masculina, essas mulheres tiveram que suprimir certas particularidades de si mesmas para enquadrar-se nos padrões de comportamento masculinos, calcados sobretudo na esfera pública.

A partir desses apontamentos, defende-se que o principal objetivo da autobiografia elaborada por Marina Núñez del Prado é o de ressaltar sua trajetória profissional. Os argumentos elaborados por Witzling também vão na mesma direção: "Uma autobiografia escrita para publicação na velhice de uma artista, [...] pode ter sido escrita como a reafirmação de sua criatividade juvenil, destinada a ser um registro público e ser lida em conformidade" (WITZLING, 1991, p. 12). Parte-se da hipótese de que a artista, já em idade avançada na data da publicação deste documento, com 65 anos, decidiu pela escrita de suas memórias com o propósito de reafirmar sua conexão com o meio artístico. Nesse sentido, teria assumido o papel de perpetuadora da própria memória. Vislumbrando a relativa falta de espaço para sua obra nos museus e narrativas canônicas da história da arte latino-americana do século XX, a artista tomou as rédeas deste processo de reconhecimento ${ }^{4}$. De fato, sua autobiografia está repleta de descrições de encontros com importantes artistas. É provável que o intuito destas descrições fosse

\footnotetext{
4 De modo geral, a artista obteve relativo reconhecimento na Bolívia, país no qual sua obra é destacada no Museu Nacional de Arte e no Museo de Arte Antonio Paredes Candia. Além disso, importantes publicações bolivianas, que se debruçam sobre a arte desenvolvida por artistas desse país, destacam o protagonismo da artista no desenvolvimento da escultura local. Por outro lado, sua obra não está representada em importantes coleções de arte latino-americana do século XX, tais como a do Museu de Arte de Buenos Aires (MALBA) ou a do New York Museum of Modern Art (MoMA). Com relação a publicações panorâmicas acerca da arte latino-americana do século XX, seu nome é praticamente desconhecido.
}

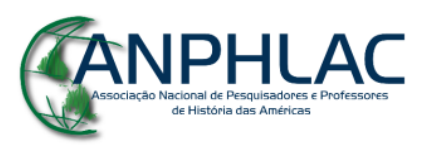


o de evidenciar a sua inserção no campo e apresentar artistas que, segundo seu julgamento, eram merecedores de destaque. Descrições de visitas a museus, exposições e ateliês também recebem grande espaço em seu texto como evidências de seu processo de desenvolvimento enquanto artista e pensadora. No trecho a seguir, a artista afirma que sua conexão com a arte seria inclusive algo muito próximo de um fervor religioso que tomou a centralidade de sua vida:

Al abrazar mi cruz artística, no lo he hecho por un afán de exhibicionismo, ni por ningún interés innoble; lo he hecho por vocación casi religiosa. Toda mi vida la he consagrado a la religión del arte y todo lo que he podido lograr en esta dolorosa ascensión. es debido a mi propio esfuerzo. (DEL PRADO, 1973, p. 88)

Tal como descrito por Núñez del Prado, seu encontro com a arte estaria permeado por uma vocação "quase religiosa", como se tivesse recebido um "chamado" que a teria encaminhado nessa direção. Witzling ressalta que essa seria uma característica comum das autobiografias escritas por mulheres artistas na segunda década do século XX, caracterizadas por narrativas com propósitos específicos, sobretudo profissionais, a serem alcançados. Ao descrever as autobiografias elaboradas por Georgia O'Keeffe e Cecilia Beaux, afirma que “elas seguiram este padrão [...], cada uma revelando uma importante experiência visual inicial que as marcou como artistas, então procedendo aos detalhes de sua educação" (WITZLING, 199, p. 12). No texto de Marina Núñez del Prado também existem passagens nas quais a artista relata certas experiências visuais como fundamentais no seu desenvolvimento como artista. No trecho seguinte, a artista relata suas reações ao visitar o lago Titicaca pela primeira vez, com aproximadamente nove anos:

La naturaleza con toda su fuerza y belleza me habló en un lenguaje que entendí, siendo la primera vez que lo escuchaba. [...] Perspectivas, tonalidades, gamas, volúmenes, formas, se hicieron presentes ante mí, como un círculo de nuevos amigos; yo me sentía maravillada y pese a mis pocos años, dueña de una tranquilidad cercana a la plenitud. [...] Mi curiosidad de niña tocada por la inquietud artística, preguntaba todo, y la naturaleza fue mi primera maestra. Desde este lejano tiempo, he creído más que en el libro, en la voz de la naturaleza que para mí tiene mayor convencimiento, porque su lenguaje va directamente al subconsciente. [...] Desde ese lejano tiempo de mi niñez, y a lo largo de toda mi vida artística, he obedecido ciegamente a ese tratado intuitivo de estética que aprendí a vislumbrar en la montaña aquella en que, venciendo todos los obstáculos, realicé mi primer viaje en busca de mi destino artístico. (DEL PRADO, 1973, p. 7)

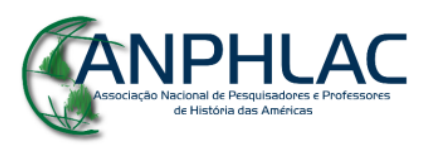

Revista Eletrônica da ANPHLAC, ISSN 1679-1061, №. 24, p. 155-188, Jan./Jun., 2018.

http://revista.anphlac.org.br 
Outro aspecto que vale ser ressaltado acerca desse documento é o destaque que Núñez del Prado dá às viagens realizadas ao longo de sua vida. Nesse sentido, existiria não apenas o intuito de construir sua identidade como artista e pensadora, mas também como "viajante do mundo". Da totalidade de páginas escritas, aproximadamente 140 estão relacionadas às viagens realizadas pela artista, nas quais os eixos centrais são suas visitas aos museus, sítios arqueológicos, pontos turísticos, e encontros com personalidades de cada localidade. Ao empreender uma análise crítica acerca deste documento, o historiador boliviano Jorge Siles Salinas corrobora esta mesma hipótese ao afirmar que:

\begin{abstract}
Es también "Eternidad en los Andes" un gustoso y ameno libro de viajes. Hay que escribir, por tanto, el nombre de la autora junto a los de otros bolivianos que han recurrido el ancho mundo y se han propuesto reproducir sus impresiones viajeras. [...] Las Núñez del Prado, unidas por una entrañable relación espiritual y artística, realizan juntas la gran aventura del conocimiento del mundo, pues saben que viajar, para una alma sensible, es descubrir y su arte es precisamente ese, el de descubrir la forma escondida que yace en el gran bloque de granito o bajo el trozo de turquesa o de plata. Una y otra, la escultora y la orfebre, han hecho en triunfo largos viajes [...] por el deseo de transmitir a otros pueblos el mensaje de Bolivia, por la necesidad generosa de ampliar y completar su visión del mundo. (SALINAS, $1980, \mathrm{~s} / \mathrm{p})^{5}$
\end{abstract}

Apesar dos relatos elaborados por Marina Núñez del Prado soarem, nas palavras de Salinas, de modo "ameno e agradável", como algo comum e corriqueiro a ser desenvolvido por uma mulher, diversos pesquisadores ressaltam o quanto a prática do relato de viagem tradicionalmente se vincula ao universo do homem branco e europeu, viajando por territórios "exóticos" no contexto da colonização e do imperialismo. Dessa forma, nas palavras de Nara Araújo, são práticas que "cumpriram um papel determinante na articulação do discurso moderno dos europeus sobre o outro e sobre si mesmos" (2008, p. 1013), não se configurando, portanto, como ingênuos, e sim como reconstruções de experiências "de vida e de encontro com um outro mundo" (ARAÚJO, 2008, p. 1013).

Para essa pesquisadora, o desenvolvimento das vias marítimas e ferroviárias no

5 O autor se refere a "Las Núñez del Prado" porque parte das viagens empreendidas por Marina contaram com a presença de sua irmã Nilda que, tal como descrito pelo autor, dedicou sua vida profissional à ourivesaria.

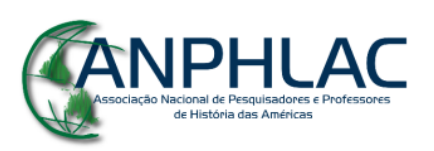


decorrer do século XIX teria proporcionado o aumento significativo das viagens internacionais, incrementando enormemente o número de homens viajantes e, em alguma medida, também o de mulheres, ainda que por questões sociais suas oportunidades fossem reduzidas: "Apesar das restrições sociais e econômicas, as mulheres se lançaram ao desconhecido, por vezes acompanhadas de seus maridos ou pais e, em outras ocasiões, por motivos próprios, de saúde, prazer ou trabalho" (ARAÚJO, 2008, p. 1012). Diversos importantes estudos foram realizados nos últimos anos de modo a compreender a dinâmica dos relatos e livros de viagem elaborados por mulheres do século XIX. Dentre eles, Stella Maris Scatena Franco, em "Peregrinas de outrora: Viajantes latino-americanas no século XIX", pesquisa os escritos de três personagens: Gertrudis Gómez de Avellaneda, Nísia Floresta e Eduarda Mansilla de Garcia. Para esta autora, a análise desses documentos se inscreveria numa "dupla contra-mão" (FRANCO, 2008, p. 8), por se tratarem de relatos produzidos por mulheres, e, além disso, latino-americanas, rumo ao continente europeu.

Evidentemente, algumas diferenças substanciais marcam o lugar social reservado às mulheres entre os séculos XIX e XX. Ainda assim, ao publicar suas próprias histórias de viagem pelo mundo afora, Marina Núñez del Prado operou uma série de deslocamentos com relação ao lugar comum do relato de viagem, atuando em diversas "contra-mãos", tal como anunciado por Franco: por ser mulher; por ser latinoamericana; por viajar apenas na companhia de uma outra mulher, sua irmã Nilda; por decidir publicar esses relatos, agregados à sua autobiografia, ainda em vida.

Especificamente com relação a este último ponto, ao analisar relatos selecionados de mulheres viajantes no século XIX, Miriam Lifchitz Moreira Leite relata que "a maioria delas não tinha a intenção de ser publicada. A publicação foi feita por descendentes após a morte da autora" (2000, p. 129-143). Esse dado também se relaciona ao fato de que, de sua posição como mulheres, essas autoras tinham, tal como aponta Nara Araújo, "uma relação conflituosa com os saberes e o conhecimento" (2008, p. 1013), proveniente de uma cultura que julgava a mulher menos desenvolvida intelectualmente que o homem:

La inseguridad o incomodidad que las viajeras del XIX sienten frente a la verdad hace que en ocasiones se sirvan de estrategias retóricas de minusvalía, propias a la escritura femenina hasta ese siglo, mediante las cuales las autoras-narradoras-protagonistas se aseguran de dejar la posibilidad abierta al

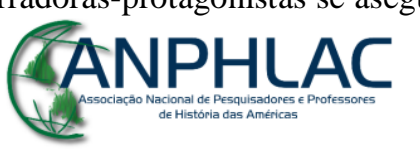


De modo interessante, não foram encontrados argumentos de menosprezo ou insegurança com relação à escrita ou à produção artística na autobiografia de Marina Núñez del Prado. Em realidade, o tom do documento é, em grande medida, de extrema confiança em si própria. Tal como indicado anteriormente por Mara R. Witzling, esse dado pode revelar o desejo de construção de uma imagem pública "sem contradições", sem ressalvas, cujo objetivo central é afirmar-se como uma artista bem sucedida.

Após a publicação da autobiografia em 1973, foram surgindo, no decorrer dos anos, algumas análises e comentários críticos de intelectuais bolivianos buscando interpretar os conteúdos apresentados pela artista. Grande parte do que foi escrito naquele momento esteve pautado nas palavras da própria artista, seguindo tanto sua cronologia quanto suas interpretações. Como exemplo, em Los mitos profundos de Bolivia, Guillermo Francovich reafirma a conexão de Núñez del Prado com os elementos místicos e transcendentais andinos, um dos argumentos centrais utilizados pela artista ao escolher o título Eternidad en los Andes:

Cuando en 1973 publicó sus memorias, en un grueso y bello volumen de más de cuatrocientas páginas, la mitad de las cuales son espléndidas fotografías de sus más importantes esculturas, les dio el título de "Eternidad en los Andes". Con ese título quería indicar Marina que en su obra, de la que el libro daba cuenta, se hallaba a su juicio contenido lo que de perenne tienen los Andes, aquello que por encima de lo puramente geográfico y de su naturaleza material les confiere una mística trascendencia. (FRANCOVICH, 1980, p. 45)

O contato entre Francovich e a artista já existia desde 1948, quando o intelectual era reitor da Universidad de Sucre e convidou Núñez del Prado para realizar uma exposição individual naquele espaço. Foi nessa conjuntura que a artista conheceu Gil Imaná, futuro presidente de sua fundação em La Paz. No centenário da artista em 2008, Imaná publicou o artigo Marina, escultora de América, narrando essa história e celebrando a amizade que teria surgido daquele encontro:

Conocí a Marina en 1948 en Sucre cuando realizó una exposición en la Universidad y fue el rector Don Guillermo Francovich quién nos presentó. La obra de Marina me impactó mucho: rostros tallados a golpe de gubia y en particular, una cabeza con una expresión muy fuerte: un rostro indio. [...] Marina es un símbolo de unión entre Perú y Bolivia. Vivió en Lima 25 años, casada con el escritor peruano Jorge Falcón. En 1995, visitándolos con Inés

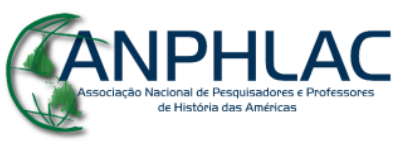


[...] caminando por la arena suave y las rocas volcánicas casi negras, ella nos dijo: "Estoy muy satisfecha con lo que he hecho, pero falta todavía algo, quisiera vivir 100 años", a lo que yo le dije: "Sí, Marinita, vivirás". A los cinco meses de ese último encuentro, Maria moría en Lima. (IMANÁ, 2008, p. 10)

Para além de Francovich, Jorge Siles Salinas também empreendeu a tarefa de produzir uma crítica de Eternidad en los Andes, publicada no suplemento cultural ilustrado do jornal El diario em 1980, sete anos após a publicação do livro. Em termos gerais, retoma a trajetória de Marina Núñez del Prado, salientando que

\begin{abstract}
Después de haber compuesto tantas piezas dignas de ingresar en los museos y de figurar en el legado universal del arte contemporáneo, nuestra escultora nos ofrece otra obra estupenda, hecha [...] en el material en que se hace la poesía y en que se expresa la ordenada secuencia del razonar humano: la palabra. Como síntesis y testimonio de todo lo que hasta aquí ha dado su grande espíritu, nos da ahora su libro: "Eternidad en los Andes". [...] Pertenece este volumen a un género poco cultivado entre nosotros: el de las Memorias. Los escasos memorialistas con que cuenta nuestra literatura han sido, por lo general, políticos, militares, diplomáticos. Raras veces los hombres de letras nos han transmitido sus experiencias. Hasta ahora, ningún artista había intentado describir junto con sus recuerdos y evocaciones, el proceso de su própria obra, la forma en que emergió de su espíritu, en fácil o doloroso esfuerzo de creación, la serie continuada de sus cuadros, de sus figuras, de sus proposiciones plásticas o musicales. El libro cuya aparición celebramos tiene un interés fundamental: un artista cuenta en cómo nació su vocación, cómo realizó su aprendizaje, la evolución que siguió su estilo, cuáles fueron sus técnicas y qué procedimientos se vio inducida a utilizar. (SALINAS, 1980, p. 54)
\end{abstract}

Ao analisar a autobiografia, Salinas evidencia a falta de escritos memorialísticos de artistas e intelectuais bolivianos, ressaltando o pioneirismo de Núñez del Prado no campo, trazendo para o público a possibilidade de ter acesso às experiências de uma artista, assim como à forma pela qual ela trabalhou com sua própria memória. $\mathrm{O}$ autor também elenca quais teriam sido os temas centrais mobilizados pela artista no documento: o primeiro seria o da "criação artística", seguido da "arte e suas manifestações através do tempo". Assim, o autor corrobora a hipótese de que o foco de Núñez del Prado estaria na esfera profissional, e não pessoal:

"Eternidad en los Andes" es, pues, un testimonio de altísimo valor de una artista acerca del arte, de su esencia y de la más honda significación espiritual. Quien quisiera hallar en él confesiones íntimas o actitudes de crítica social o política saldría con la sensación de haber intentado una búsqueda carente de sentido, pero recompensado, en cambio, con otros hallazgos, de significación mucho mayor, pues son los que atañen a la esencia

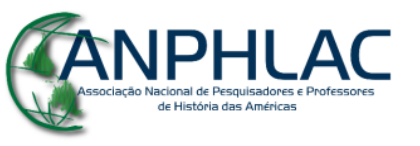

Revista Eletrônica da ANPHLAC, ISSN 1679-1061, №. 24, p. 155-188, Jan./Jun., 2018.

http://revista.anphlac.org.br 
O autor destaca a ausência de "confissões íntimas" ou "políticas" no documento, evidenciando apenas algumas passagens nas quais a artista se lamenta acerca da falta de atenção para sua obra por parte dos governantes bolivianos. Apesar disso, Salinas ressalta que a artista teria conseguido elaborar um texto carregado de "leveza e simplicidade", atributos geralmente associados à escrita feminina. Ainda assim, ao evidenciar o caráter público da autobiografia, Salinas reitera o desejo de Núñez del Prado em se projetar como uma artista profissional e, portanto, focada em sua atuação como figura pública.

\section{Transformar a vida em imagem}

Eternidad en los Andes contém 217 páginas dedicadas a reproduções de fotografias e obras da artista. Em termos gerais, esse grande arcabouço de imagens concentra-se nas seguintes temáticas: cenas de infância, retratos da família e da artista, fotografias de paisagens e monumentos, exposições, obras, prêmios, eventos sociais, e fotografias da Casa-museo Núñez del Prado em La Paz. Neste item, algumas dessas imagens serão analisadas conforme os vínculos que estabelecem com a narrativa textual de Núñez del Prado. Como veremos, elas estão em constante diálogo com o conteúdo elaborado na autobiografia, trazendo um respaldo visual ao caráter público e profissional que a artista buscou dar a essas memórias.

Tal como no processo de elaboração de seu texto autobiográfico, as imagens selecionadas pela artista também passaram por uma seleção prévia, condizente com seus objetivos e diretrizes. Novamente, deparamo-nos com a construção da narrativa elaborada pela artista que, nesse caso, configura-se como uma narrativa sobretudo visual. Em termos metodológicos, Artières sugere alguns encaminhamentos interessantes acerca desse tópico. Ainda que se debruçando sobre a prática de elaboração específica de álbuns fotográficos, para nós seus comentários são válidos por abordarem os processos de seleção de imagens:

Não colocamos qualquer foto nos nossos álbuns. Escolhemos as mais bonitas ou aquelas que julgamos mais significativas; jogamos fora aquelas em que alguém está fazendo careta, ou em que aparece uma figura anônima. E depois

\section{BANPHLAC}


as ordenamos esforçando-nos para reconstruir uma narrativa. Quando a foto é muito enigmática, acrescentamos um comentário. [...] Acontece também, com o tempo, de algumas fotos serem retiradas, porque são comprometedoras, porque não são condizentes com a imagem que queremos dar de nós mesmos e da nossa família. [...] O essencial é que em alguns minutos, uma hora no máximo, possamos justificar o tempo passado e sua coerência. (ARTIÈRES, 1998, p. 9-34)

Outra reflexão central diz respeito à temporalidade das imagens. Ainda que num primeiro olhar possamos associá-las ao passado, carregando-as de nostalgia e de memória, Annateresa Fabris atenta que, em realidade,

o álbum é concebido como um documento para a posteridade. Antes do que o presente, sua construção objetiva parte de uma memória pensada em termos de futuro, visto corresponder ao desejo de sobreviver à morte como espécie, como sobrenome, como classe e como origem. (FABRIS, 2011, p. 9)

A autora ressalta que o álbum, assim como a fotografia, seria simultaneamente "memória" e "ruína", testemunha do processo de envelhecimento e da própria passagem do tempo, e o vislumbre da possibilidade de reconhecimento futuro.

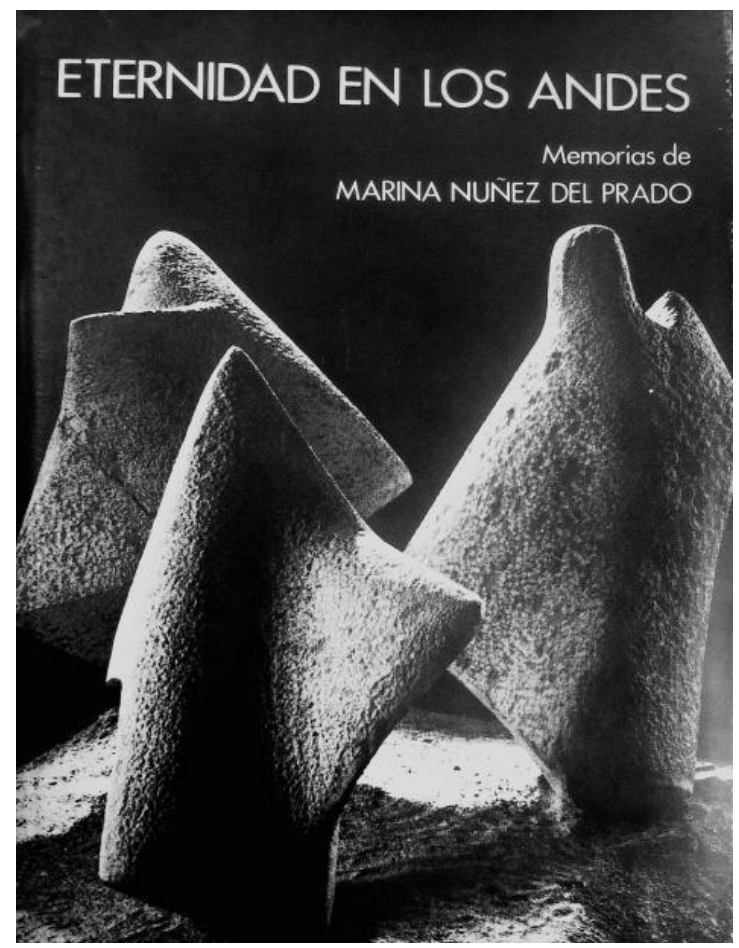

Figura 1. Marina Núñez del Prado. Eternidad en los Andes (capa do livro). Santiago: Lord Cochrane, 1973.

A primeira imagem selecionada é a capa da única edição de Eternidad en los

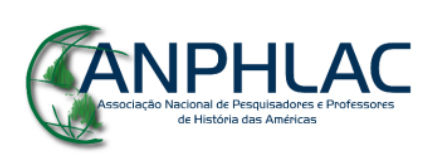

Revista Eletrônica da ANPHLAC, ISSN 1679-1061, №. 24, p. 155-188, Jan./Jun., 2018.

http://revista.anphlac.org.br 
Andes. Nela, observa-se a reprodução em fotografia da escultura Mujeres Altiplánicas. Muito provavelmente, Marina Núñez del Prado escolheu essa imagem dentre tantas outras por considerá-la representativa daquilo que considerava singular e relevante em sua produção. Essa escultura, datada de 1970, foi elaborada em uma fase avançada da carreira de Núñez del Prado, momento no qual a artista já havia desenvolvido em parte aquilo que caracterizaria sua produção em termos formais e temáticos: a representação da mulher indígena andina através de uma linguagem que tende ao abstrato.

Essa obra em particular ressalta outro elemento central da produção de Núñez del Prado: esculturas elaboradas em pedra praticamente sem polimento. Tal como se observa por conta da textura rústica das peças, estabelece-se uma semelhança estética entre o chão de areia - representação do mundo natural - e as três peças representações das mulheres altiplânicas. Em termos metafóricos, a artista propõe uma união entre o mundo natural e o mundo humano, associação veementemente destacada em sua autobiografia como sendo característica do universo indígena andino. Outro dado que chama a atenção é a ausência de fisionomia de suas personagens, cuja representação é em grande medida abstrata, ainda que se identifiquem os contornos dos corpos. Nesse caso, é provável que a artista estivesse procurando trazer à tona elementos que transcendem as próprias identidades individuais, em busca da essência da "mulher altiplânica".

Com relação à transposição dessa obra escultórica, tridimensional, para uma fotografia, vale destacar que o fundo escuro e a iluminação foram cuidadosamente pensados para criar um efeito de grande contraste entre luz e sombra, evidenciando não apenas a textura das peças, mas o ambiente de introspecção, silêncio e mistério, característico da noite. O ângulo em que a fotografia foi tomada evidencia as posições divergentes das três figuras, ressaltando a sensação de movimento em círculo, tal como numa dança. Esse movimento, sem início nem fim, está fortemente associado ao título da autobiografia, Eternidad en los Andes, que remete a noção de tempo circular ou mítico, elemento norteador e mitológico de muitas tradições indígenas latinoamericanas. Tal como aponta José d'Assunção Barros,

o Tempo Mítico, de modo geral, apresenta uma estrutura circular. Além disto, trata-se de um tempo reversível - se não através do próprio mito, que realiza o retorno em sua própria narrativa ou repetição cíclica, ao menos através do 'rito', que corresponde a um retorno ritual 'as origens'. (BARROS, 2010, p. 181)

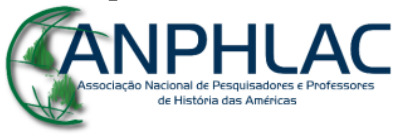




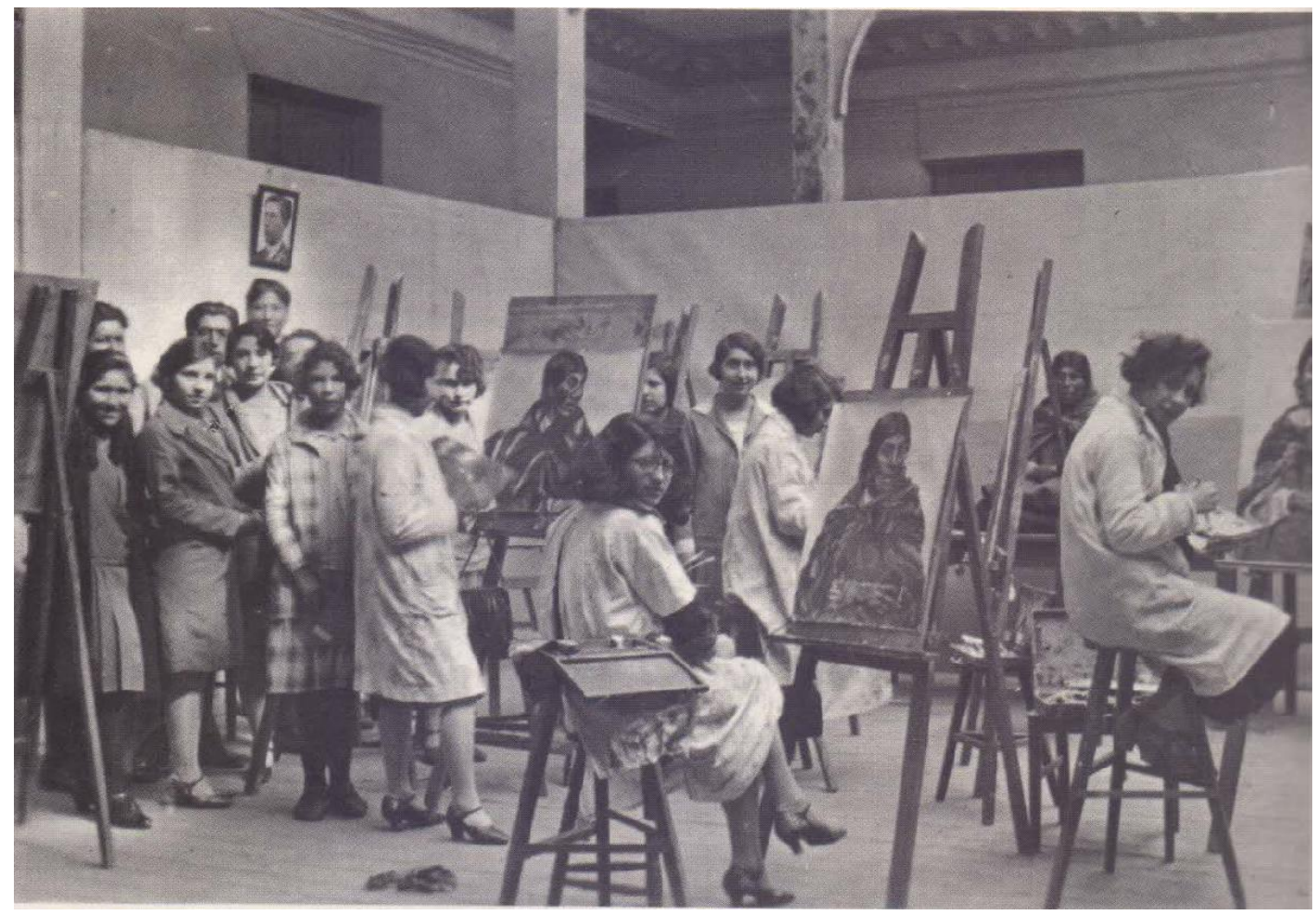

Figura 2. "Clase de pintura, Academia de Bellas Artes, La Paz, Bolivia (primera desde la derecha)". Foto: Reproduzida no livro Eternidad en los Andes. Santiago, Editorial Lord Cochrane, 1973.

Na fotografia acima, alunas da Academia Nacional de Bellas Artes de La Paz realizam um exercício de pintura a partir da observação de um modelo vivo, entre os anos de 1927 e $1929^{6}$. Aqui, retornamos ao período de formação artística de Marina Núñez del Prado, fundamental para sua aproximação ao indigenismo, um dos pilares de convergência de muitas de suas produções. Como veremos, o indigenismo em suas vertentes artísticas privilegiou representações figurativas do universo indígena. No caso de Núñez del Prado, a artista trabalhou extensivamente com essas representações até a década de 1940, quando se mudou para a cidade de Nova York e aproximou-se das correntes abstratas. Ainda que tenha transformado a forma através da qual elaborava suas representações, o conteúdo temático desenvolvido permaneceu, em grande medida, vinculado às questões indigenistas. A escultura Mujeres altiplánicas é representativa desse encontro entre a temática indigenista e a forma abstrata.

Na Figura 2, é possível observar Marina Núñez del Prado sentada num dos

6 Não se sabe a data exata da fotografia. Contudo, Marina Núñez del Prado frequentou a Academia Nacional de Bellas Arte de La Paz entre os anos 1927 e 1929.

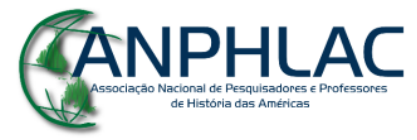

Revista Eletrônica da ANPHLAC, ISSN 1679-1061, №. 24, p. 155-188, Jan./Jun., 2018.

http://revista.anphlac.org.br 
bancos, à direita. Nesse caso, o modelo vivo é uma senhora sentada ao fundo da imagem, na lateral direita, com fortes feições indígenas. Com o corpo envolto por um poncho tradicionalmente utilizado pelas populações da região andina e os cabelos longos trançados, é observada e representada por jovens de cabelos curtos, vestidas à moda europeia, com saias longas, meias finas e sapatos de salto alto. O contraste entre as jovens que realizam o exercício e a mulher ao fundo, que é observada, é notório. A análise dessa imagem é extremamente rica por evidenciar o tipo de representação que era incentivada aos seus alunos pela Academia Nacional de Bellas Artes de La Paz.

Ao analisar a formação dessa Academia, Michela Pentimalli retoma sua fundação pelo presidente Hernando Siles, em 1926, ressaltando que seus dois primeiros diretores, Humberto Beltrán de Oliveira e Alejandro Guardia, formados na França e na Itália respectivamente, defendiam um ensino marcado pelas diretrizes classicistas "do modelo acadêmico romano, que Alejandro Guardia, diretor e docente, autor dos programas da Academia, havia experimentado durante seu processo pessoal de aprendizagem" (PENTIMALLI, 2009, p. 71). Ainda assim, a fotografia acima assinala que, mesmo direcionada no sentido dos modelos clássicos, essa Academia foi tensionada pelas correntes modernistas, e nesse caso indigenistas, desde os primeiros anos de funcionamento, com aulas nas quais suas alunas realizavam retratos a partir da observação de modelos-vivos indígenas.

Depois de uma longa passagem pela Espanha, onde se formou na Real Academia de Bellas Artes de San Fernando, e por Paris, onde estudou na École Nationale Supérieure des Beaux-Arts, o pintor Cecilio Guzmán de Rojas foi convidado pelo presidente Hernando Silles, em 1930, para ser diretor da Dirección General de Bellas Artes. Foi nesse contexto que as diretrizes gerais de produção artística na Academia se direcionaram ainda mais no sentido da exaltação da figura indígena, assim como de costumes e hábitos dessa parcela da população. Tal como declarado pelo próprio Rojas, "graças à arte se fez justiça ao nosso irmão indígena, exaltando-o e mostrando os encantos de sua alma, que é a alma da América" (ROJAS Apud PENTIMALLI, 2009, p. 71).

Dentre suas ações mais destacadas, consta a atenção ao patrimônio artístico boliviano, que carecia da devida conservação e catalogação. Rojas foi responsável pela transformação da Casa de la Moneda de Potosí em um grande museu e pela condução

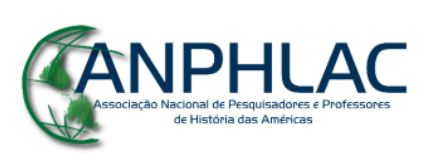


de diversos processos de restauro de importante obras da História da Arte boliviana, como as do pintor Melchor Pérez de Holguín, tradicionalmente associado ao barroco dos séculos XVII e XVIII (MENDIETA, 1999). Para Michela Pentimalli,

a influência profunda dos pressupostos teóricos e formais do indigenismo, difundidos pelo exemplo e ensino de Guzmán de Rojas, deixou a semente de renovação da arte nacional nas jovens gerações de artistas que frequentaram a Academia. (PENTIMALLI, 2009, p. 75)

Ainda em 1930, Núñez del Prado foi escolhida para ser professora das disciplinas de "Escultura" e "Anatomia Artística" na Academia Nacional de Bellas Artes de La Paz, sendo que, segundo seu relato, "por incitação de Guzmán de Rojas [...] e apesar de que eu não me sentia nem com idade nem preparada adequadamente para a docência, apresentei-me ao concurso de méritos para uma cátedra" (DEL PRADO, 1973, p. 35). Após tornar-se diretor da Dirección General de Bellas Artes, Rojas optou por demitir grande parte dos professores da Academia, convocando novos concursos, de modo a montar uma equipe comprometida com suas pautas políticas. A escolha de Marina Núñez del Prado, portanto, também pode ser interpretada através das motivações políticas levadas a cabo por Rojas que, segundo a própria artista, representavam "[...] novos conceitos sobre o ensino artístico, já não mais gessos nem cópias de figuras clássicas" (DEL PRADO, 1973, p. 35).

Foram nestes anos que os alunos da Academia, em sua maioria "criollos" de descendência europeia, passaram a ser incentivados a produzir obras que representassem o universo indígena andino, utilizando-se amplamente da fisionomia dessas populações. Em busca de afirmar uma identidade comum boliviana, essas produções elegeram o elemento social e indígena, como central à criação artística, demonstrando uma atenção ao cenário mais amplo do indigenismo andino.

Em termos gerais, o indigenismo andino da primeira metade do século XX é definido por Antonio Cornejo Polar (1994) como "um momento de manifestações do que se denomina nacionalismo cultural latino-americano". Polar indica que nesse contexto se configurou uma associação entre regionalismo e nacionalismo, pois ao mesmo tempo em que as recentes nações latino-americanas buscavam suas origens précoloniais e identidades nacionais, no intuito de se afastarem da influência colonizadora

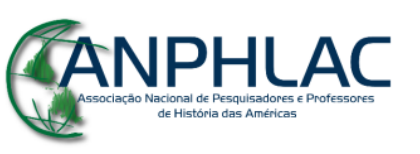


no campo simbólico, utilizavam-se desses mesmos recursos para um crescente processo de modernização (POLAR, 1994). Ainda que não seja pertinente estabelecer um vínculo unidirecional entre indigenismo e nacionalismo, a problemática indígena não poderia ser concebida separadamente da ideia de nação, e, desta forma, "não poderia aparecer antes que as antigas colônias espanholas se constituíssem em sociedade definidas pela lógica do Estado-Nação” (MAJLUF, 1994, p. 617). Portanto, teria sido nesse cenário que o chamado "problema do índio" teria aparecido de maneira definitiva, por conta da "ideia moderna de uma nação étnica e culturalmente homogênea [...] que dominou de forma persistente os programas de estadistas e pensadores da cultura desde o século XIX” (MAJLUF, 1994, p. 617).

Nos campos político e cultural, esses processos foram pautados por discussões sobre os problemas sociais latino-americanos, gerando, ainda que de maneira difusa, uma consciência nacional mais atenta ao mundo indígena e a desintegração cultural e material a que esta parcela da população estava cada vez mais submetida. ${ }^{7} \mathrm{Na}$ primeira metade do século XX, o crescimento acelerado do número de indígenas sem posse de terra empurrou um grande contingente populacional para a marginalidade, no campo e na cidade. Nesse contexto, tanto indígenas como camponeses passaram a se organizar para reivindicar do Estado uma expressão política da qual estavam até então excluídos, num processo marcado por grandes enfrentamentos, com a organização de sindicatos operários, mineiros e mobilizações cada vez mais frequentes (BAO, 1990). Especificamente no caso da Bolívia, foi apenas na revolução de 1952 e gestão do presidente Paz Estenssoro que o diálogo entre essa parcela da população e o estado boliviano se tornou mais efetivo. Dentre as ações encabeçadas por Estenssoro, é importante destacar a instauração do sufrágio universal e da reforma agrária, a nacionalização das minas, a fundação da Central Obrera Boliviana (COB), a reforma do exército e da educação.

\footnotetext{
7 A partir da segunda metade do século XIX, as reformas liberais implementadas pelas novas repúblicas aceleraram o processo de desestruturação das propriedades comunais indígenas iniciado na colonização. Constituindo-se como um dos principais pilares estruturantes da vida indígena, essas terras tiveram as "tradicionais atividades mercantis da economia de subsistência da comunidade [...] redirecionadas para atender as necessidades do setor comercial" (SOARES \& COLOMBO, 1999, s/p.).
} 


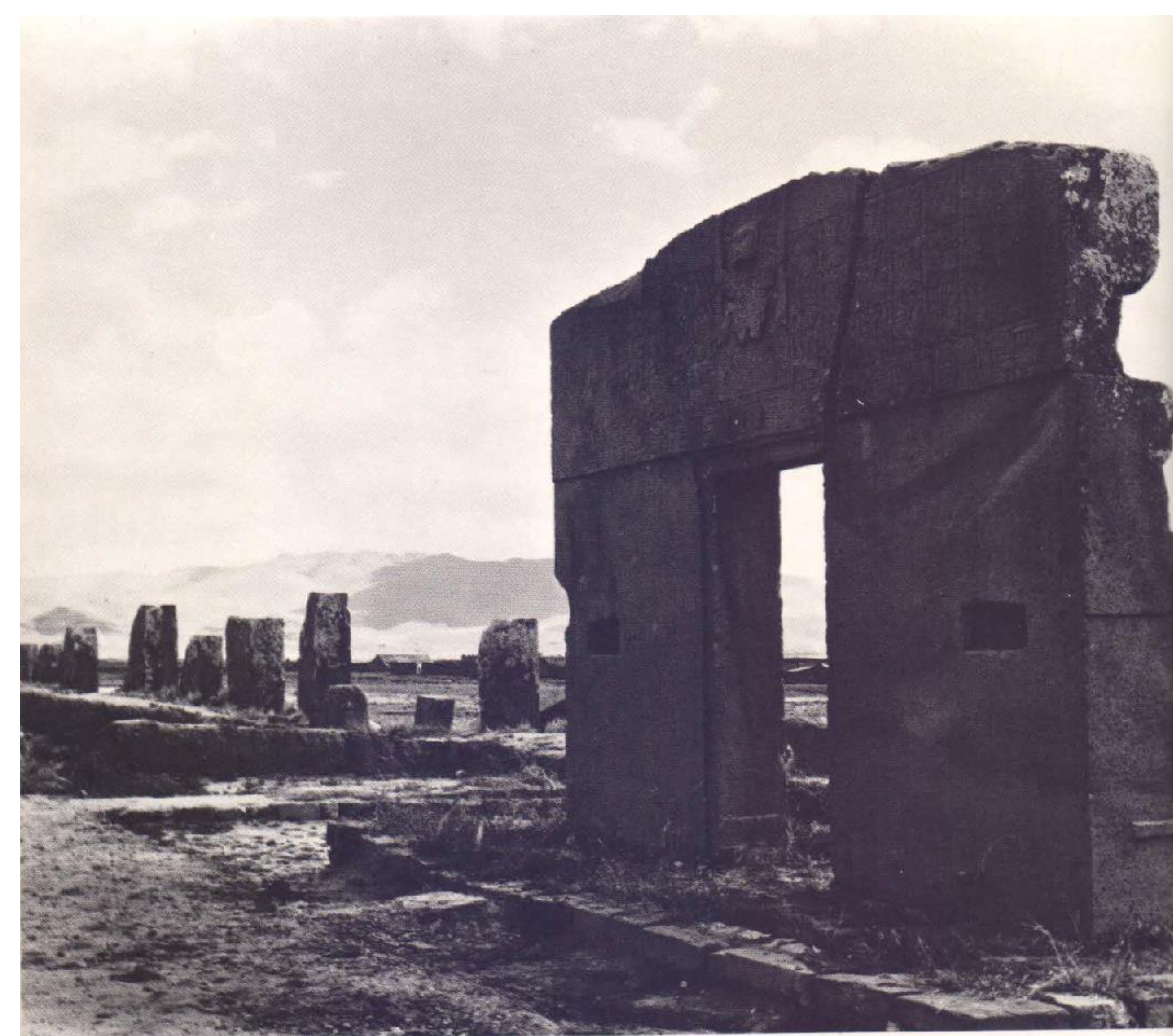

Figura 3. "'Puerta del sol'; Tiwanaku, La Paz, Bolivia”. Foto: Reproduzida no livro Eternidad en los Andes. Santiago, Editorial Lord Cochrane, 1973.

Na Figura 3, observa-se uma fotografia da Puerta del sol, localizada na zona arqueológica boliviana de Tiwanaku. Essa reprodução compõe a primeira série de imagens intercaladas ao texto de Núñez del Prado, sendo uma das únicas que não se refere diretamente ao seu universo pessoal - familiar, educacional, artístico. Nesse sentido, é como se a artista optasse por incorporar certos símbolos pré-hispânicos à sua identidade pessoal, que passam a representar não apenas um passado remoto, mas uma realidade a partir da qual seria possível construir o pensamento e a linguagem artística. Em seu texto, ela ressalta o elo existente entre sua vida, obra, e conexão ao universo indígena e andino:

Mi vida es mi obra: Siento la inmensa dicha de haber nacido bajo la tutela de los Andes que son la expresión de la fuerza y el milagro cósmico. Así mi obra expresa el espíritu de mi tierra y el espíritu de mi gente aymara. (DEL PRADO, 1973, p. 24)

Esse movimento de incorporação de simbologias pré-hispânicas não se deu apenas em nível individual - como no caso de Marina Núñez del Prado -, mas também

\section{GANPHLAC}

Revista Eletrônica da ANPHLAC, ISSN 1679-1061, №. 24, p. 155-188, Jan./Jun., 2018.

http://revista.anphlac.org.br 
a nível nacional, representando uma verdadeira transformação dos imaginários na América Latina ao longo do século XX através de uma crescente valorização dos monumentos pré-hispânicos, que passaram a ser paulatinamente incorporados aos repertórios nacionais. Preocupados com a construção de uma história nacional oficial para seus respectivos países, governantes investiram recursos públicos em museus ${ }^{8}$, monumentos públicos, desfiles cívicos e reformas urbanísticas que pudessem destacar a modernização da nação e de seus símbolos, cuidadosamente selecionados.

Com relação especificamente à valorização dos monumentos pré-hispânicos no cenário boliviano, Marcos R. Michel López argumenta que esse processo foi iniciado com a própria formação do Estado Nacional, no qual

a arqueologia constituiu-se como um meio populista que proclamava a origem comum do boliviano em uma cultura: Tiwanaku, como reflexo do projeto de uma nação monocultural e essencialmente andina. (LÓPEZ, 2009, p. 4)

Essa zona arqueológica, uma das maiores do país, abrigou uma importante civilização pré-incaica no período entre 1500 a.C. a 1000 d.C., aproximadamente. Para esse autor, foi com a ascensão do Movimiento Nacionalista Revolucionario (MNR) ao poder em 1952 que se configurou o que ele denomina como "arqueologia nacionalista", centrada também em Tiwanaku, "seu monumentalismo, e a busca pela implementação de símbolos comuns para a criação de uma nação mestiça" (LÓPEZ, 2009). No mesmo sentido desse argumento, Claudia Rivera Casanovas e Matthias Strecker ressaltam que, ao afirmar que "a grandiosidade de Tiwanaku era o antecedente direto da sociedade boliviana, [...] os ideólogos do Estado Nacional forjaram nexos diretos com um passado 'glorioso' e 'unificador"' (CASANOVAS; STRECKER, 2005), solapando simultaneamente representações de outras civilizações pré-hispânicas, relegadas naquele momento ao segundo plano.

\footnotetext{
8 Sobre a temática dos museus, vale citar a pesquisa de Camilo de Mello Vasconcellos, cujo foco é o Museo Nacional de Historia do México. O autor ressalta que o intuito de "unificação nacional por meio do Museu deve ser entendido como uma visão de história comprometida com o poder e os seus representantes e que, nessa circunstância, não seria o lugar da crítica e da reflexão, mas da versão única que deveria ser conhecida e compartilhada por todos os seus visitantes, mascarando assim as contradições e os conflitos sociais existentes" (VASCONCELOS, 2007, p. 59).
}

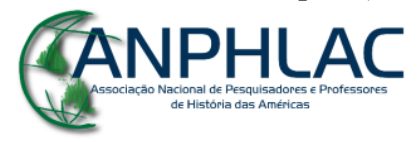

Revista Eletrônica da ANPHLAC, ISSN 1679-1061, №. 24, p. 155-188, Jan./Jun., 2018.

http://revista.anphlac.org.br 
Em 1952, Víctor Paz Estenssoro nomeia Carlos Ponce Sanginés como diretor do Instituto Indigenista Boliviano. López afirma que

o trabalho arqueológico de Ponce centrou-se no aprimoramento do sítio
arqueológico de Tiwanaku como símbolo da nacionalidade boliviana, com
projeção política e o forte impulso do Movimiento Nacionalista
Revolucionario $(M N R)$. (LÓPEZ, 2009, p. 11)

Para Casanovas e Strecker, Sanginés foi uma das figuras centrais no projeto estatal de institucionalizar a arqueologia no país, já que sua atuação teria sido determinante na criação do Centro de Investigaciones Arqueológicas (CIAT) em 1958, e do Instituto Nacional de Arqueologia (INAR) em 1975, instituições responsáveis pelo trabalho de escavação em Tiwanaku e restauração de suas estruturas principais.

Ainda com relação à Eternidad en los Andes, a artista dedica um item a sua visita à Tiwanaku, no qual começa afirmando que "para mim, Tiwanaku não é uma cidade arqueológica em ruínas, e sim um talismã ancorado nas alturas dos Andes, a 4.000 metros acima do nível do mar" (DEL PRADO, 1973, p. 30). Ainda que não conste a data em que visitou a zona arqueológica, ela estava acompanhada, dentre outras pessoas, por Cecilio Guzmán de Rojas, então diretor da Academia Nacional de Bellas Artes de La Paz. Dessa maneira, é quase certo que a visita foi em algum momento da década de 1930. Além de Rojas, alguns arqueólogos, artistas e membros do governo compunham a comitiva, que viajava com o objetivo de observar o equinócio de inverno no dia 21 de Julho. Sobre a visita, a artista afirma que:

\footnotetext{
Enquanto o arqueólogo recitava suas fórmulas, eu me surpreendia com o friso prodigiosamente esculpido por artesãos sobre-humanos na Puerta del Sol, que naquela hora angélica da manhã parecia brilhar como uma jóia, como uma página da história do Gênesis, mais antiga que a Bíblia, escrita com personagens agradavelmente estranhos. Sob a crosta da terra marrom das ruínas, por que não supor que havia uma cidade morta, estendida como o cadáver do rei mais poderoso do mundo? (DEL PRADO, 1973, p. 31)
}

O trecho elucida como Marina Núñez del Prado dialogou com o discurso nacionalista no campo da arqueológica, manifesto através do desejo de eleger Tiwanaku como antecedente da sociedade boliviana, fruto de um 'passado 'glorioso' e 'unificador"”, tal como indicado por Casanovas e Strecker (2005). Em sua análise, ela

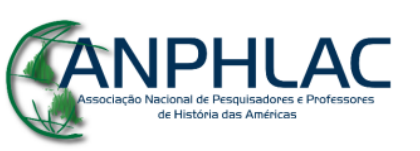

Revista Eletrônica da ANPHLAC, ISSN 1679-1061, №. 24, p. 155-188, Jan./Jun., 2018.

http://revista.anphlac.org.br 
ressalta que essa cidade seria mais antiga que a própria Bíblia, questionando a cronologia da Igreja Católica e colocando Tiwanaku como um importante centro mundial, uma "página da história do Gênesis". Em outra passagem de sua autobiografia, ela também descreve suas impressões ao visitar a zona arqueológica de Tenochtitlán, localizada no coração da Cidade do México, antiga capital do Império Mexica. Nessa citação, vale atentar para a forma como a artista descreve Tenochtitlán como uma "cidade irmã" tanto de Tiwanaku quanto da "capital de ouro de Cuzco", no Peru, destacando como a estética dessas zonas arqueológicas se configurava como fonte para suas expressões artísticas:

Um sentimento fraternal me unia, havia uma espécie de consanguinidade na estética, que era a essência de minhas expressões artísticas, com tudo o que procedia da pátria da Serpente Emplumada: México. Eu tinha a convicção de que deveria ser proclamada como capital espiritual da América indígena. $\mathrm{Na}$ época pré-colombiana, a Cidade do México tinha o belo nome indígena de Tenochtitlán, e aquela cidade, que culminou com uma pirâmide tão alta quanto um verdadeiro arranha-céu, subindo ao centro de seu entorno, pensava eu que era irmã da cidade sagrada de Tiwanaku ou da capital de ouro de Cuzco. (DEL PRADO, 1973, p. 113)

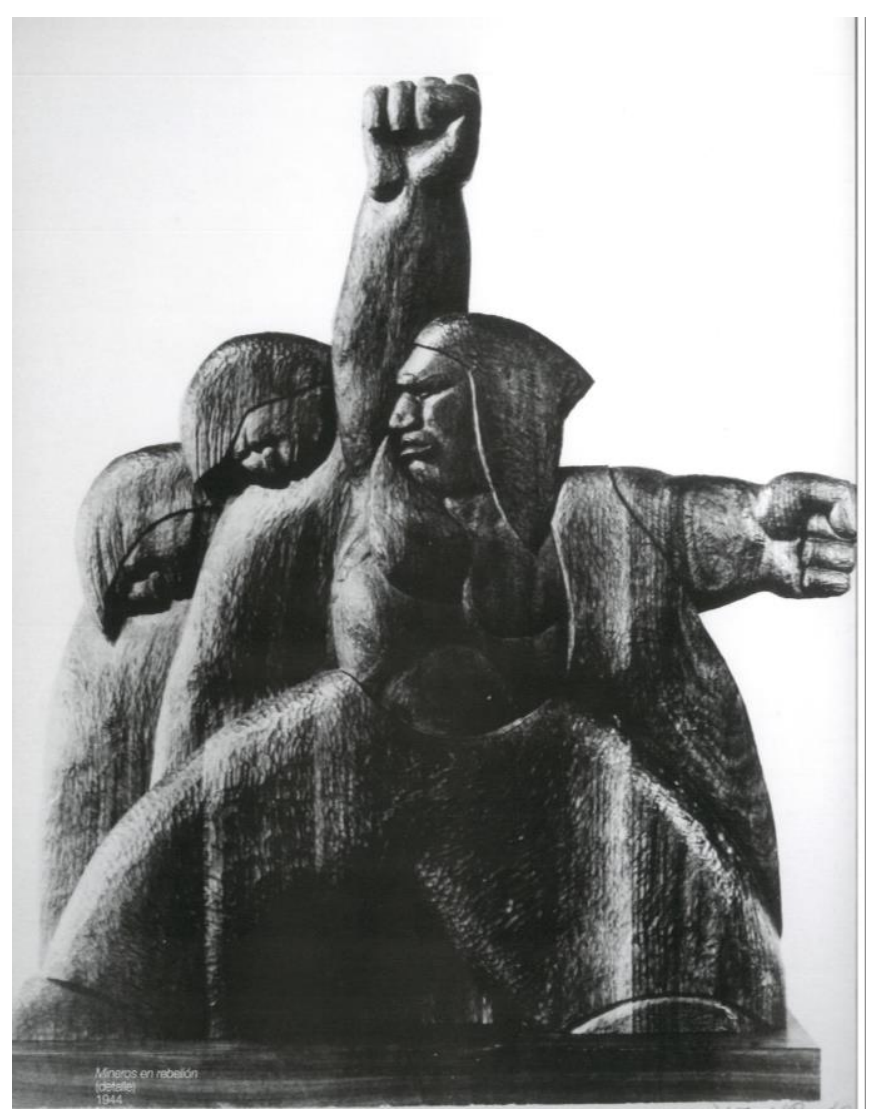

Figura 4. Marina Núñez del Prado. Mineros en rebelión, 1944. Nogal. 90X85cm. Corporación Minera Boliviana, La Paz, Bolívia. Foto: Reproduzida no livro Eternidad en los Andes. Santiago, Editorial Lord Cochrane, 1973.

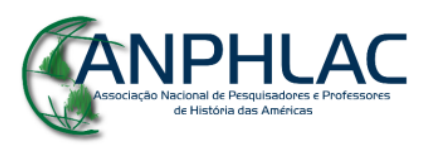

Revista Eletrônica da ANPHLAC, ISSN 1679-1061, №. 24, p. 155-188, Jan./Jun., 2018.

http://revista.anphlac.org.br 
Outra importante categoria de imagens selecionadas para a autobiografia da artista são as reproduções de obras que se destacaram ao longo das décadas, seja pela temática, pela forma, ou por prêmios e distinções recebidas por sua elaboração. Ao longo de sua vida, Marina Núñez del Prado optou por se manter afastada de debates políticos mais fervorosos, não se envolvendo diretamente com pautas de cunho social. Porém, ao longo dos anos, elaborou algumas obras pautadas por temáticas mais "combativas", tal como a escultura Mineros en rebelión [Figura 4]. A peça compõe a fase que o crítico de arte Raúl Botelho Gosálvez denominou como "período social” da obra da artista, e que se estendeu entre os anos de 1943 e 1945, durante sua estadia na cidade de Nova York. Sobre esse momento, a artista relata que:

Evoqué los años de mi infancia y mi adolescencia y recordé la humildad, la nobleza y la generosidad de mis coterráneos indígenas [...]. La vida colectiva de mi pueblo era tan pobre, tan desamparada y tan humilde. [...] A raíz de estos recuerdos, me propuse crear varios grupos escultóricos que subrayan mis sentimientos y mi protesta y los realicé en tallas directas en madera. El trabajo que goza de mi predilección es el que se conoce con el nombre de "Los mineros". (DEL PRADO, 1973, p. 109)

A obra descrita na citação como Los mineros, ficou posteriormente conhecida como Mineros en rebelión [Figura 4]. Produzida no ano de 1946, foi exibida na exposição anual da National Association of Women Artists, pela qual a artista ganhou uma medalha de ouro. Na escultura, observa-se a representação de três mineiros de fisionomia indígena que se colocam um atrás do outro. Os dois que estão ao fundo aparecem com suas cabeças abaixadas, expressando uma sensação de cansaço proveniente do trabalho exaustivo nas minas, mas que também pode indicar a árdua luta por direitos e melhores condições de vida. Quem conduz o grupo é o homem que está à frente, uma figura masculina, de liderança, com a cabeça erguida. Posicionando um de seus braços para cima e o outro para o lado, forma uma composição de cruz, indicando a ideia de uma luta que é também sagrada. A artista optou por criar uma representação na qual a figura indígena é central e forte, sendo também, simultaneamente, subjugada e levada à exaustão, sensação expressa nas faces das duas figuras em segundo plano.

\section{CANPHLAC}




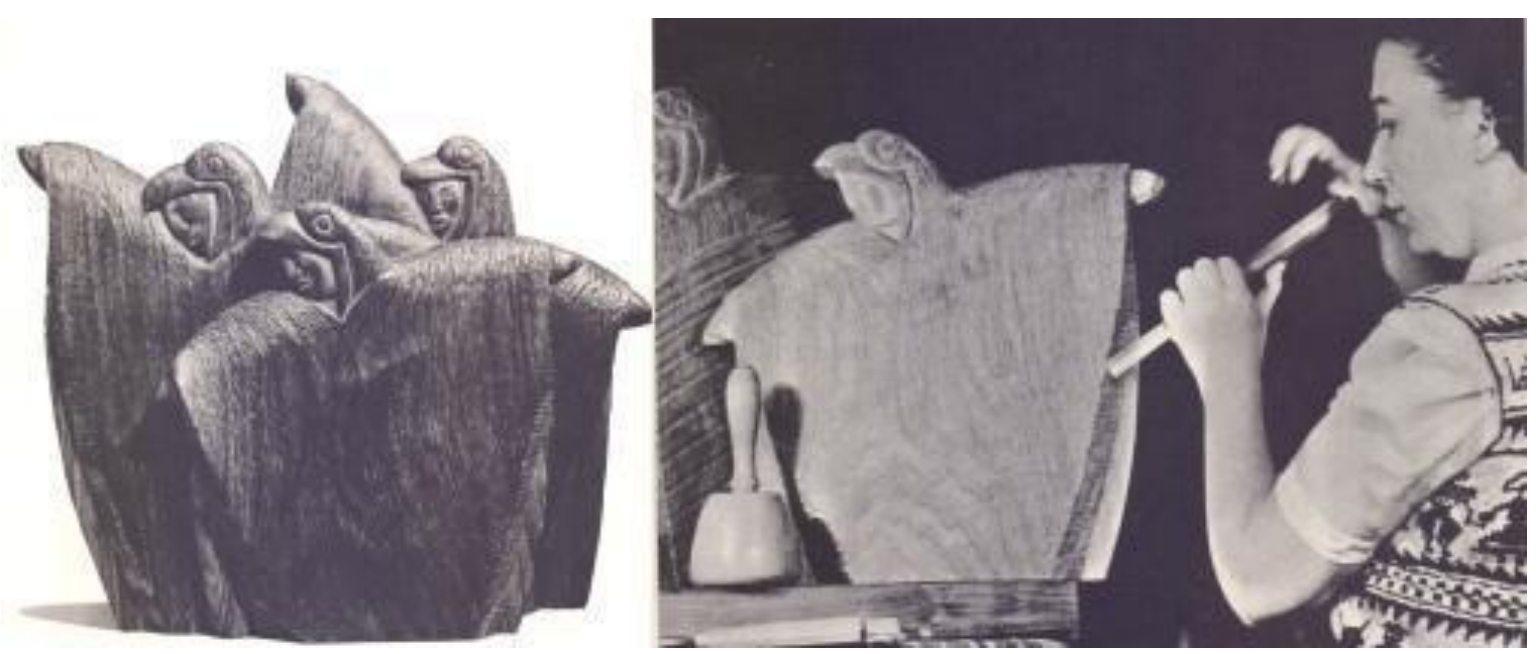

Figura 5. Marina Núñez del Prado. Danza de Cóndores, 1936. Nogal. 66X56cm. Embaixada da Bolívia, Washington, Estados Unidos. Foto: reproduzida no livro Eternidad en los Andes. Santiago, Editorial Lord Cochrane, 1973. Figura 6. "Mi taller en Buenos Aires", 1936. Foto: reproduzida no livro Eternidad en los Andes. Santiago, Editorial Lord Cochrane, 1973.

Ao longo da década de 1930, nos anos em que lecionou na Academia Nacional de Bellas Artes de La Paz e especialmente com sua mudança para a cidade de Buenos Aires em 1936, Marina Núñez del Prado elaborou uma grande quantidade de obras cujos eixos temáticos eram os costumes indígenas da região andina. Pertencente a essa categoria, a obra Danza de Cóndores [Figura 5] foi produzida ainda no começo da trajetória da artista. No catálogo Marina Núñez del Prado - Dibujos y Bocetos, Michela Pentimalli indica que, no conjunto de obras elaboradas pela artista entre as décadas de 1930 e 1940, “as temáticas abordadas [...] são particularmente distintivas do período em que a artista denominará como 'musical' e que talhará preferencialmente obras bidimensionais em madeira: lhamas, indígenas, cholas bailarinas" (PENTIMALLI, 2007, p. 9).

Segundo relatos da artista, as obras talhadas representaram seu rompimento definitivo com a linguagem acadêmica. Ainda assim, identificam-se certos elementos figurativos das personagens retratadas que, a partir de meados da década de 1940, tornam-se menos definidos em sua obra, como previamente observado na obra Mujeres Altiplánicas [Figura 1]. Essa escultura foi desenvolvida no período de contato mais íntimo da artista com as pautas do indigenismo andino, exprimindo aspectos das tradições indígenas através da temática da dança, algo amplamente valorizado dentro daquele determinado contexto.

Para uma análise mais aprofundada desse ponto, é válido destacar que não

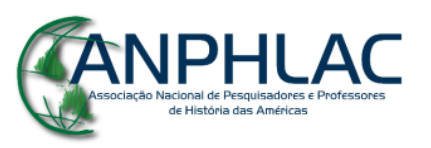

Revista Eletrônica da ANPHLAC, ISSN 1679-1061, №. 24, p. 155-188, Jan./Jun., 2018.

http://revista.anphlac.org.br 
apenas a Danza de cóndores como também outras danças representadas por Marina Núñez del Prado, ainda que naturalizadas como indígenas, foram efetivadas como prática cultural posteriormente a colonização e chegada dos espanhóis. Nesse sentido, são muito representativas do contato entre elementos tradicionais hispânicos e indígenas. Contudo, enquanto práticas executadas sobretudo pela população indígena, foram selecionadas pelos intelectuais e artistas indigenistas como representativas dessa parcela da população. Ao refletir sobre os impactos que estas referências tiveram em sua produção, ao longo da década de 1930, a artista afirma que

[...] Como el mundo en que residía era tan rico en fuerza cósmica y el elemento humano de una antigüedad remota, sus costumbres y por consecuencia sus fiestas eran un cúmulo de sugerencias. Su música de melodías tristísimas y entrañables y los movimientos tan sui generis de sus danzas me dieron el sentido del ritmo y movimiento que ha perdurado en toda mi obra escultórica. (DEL PRADO, 1973, p. 40)

Em sua autobiografia, o contato com as festas e tradições indígenas surge em diversas passagens. Logo no primeiro capítulo, intitulado Genealogia, ao descrever os familiares presentes na sua infância e juventude, a artista destaca a figura da Tiacha, irmã de sua mãe, como alguém que "foi uma eficaz auxiliar dos muitos afazeres da casa" (DEL PRADO, 1973, p. 3). Ela teria sido uma grande "porta de entrada" para este novo universo, devido às festas folclóricas nas quais tinha o costume de levar as irmãs Núñez del Prado, Marina e Nilda:

Gracias a sus afanes, conocemos mi hermana y yo, la maravillosa sorpresa de algunas fiestas folklóricas de Bolivia, cuya fama ha traspasado el ámbito nacional. Ella nos conducía [...] cada 24 de Enero a la Feria de miniaturas de "Alacitas" fiesta en la que deslumbrada yo contemplaba ese mundo de maravillas en miniatura, sobre las mesas o mostradores lucían los "Ekekos" (diocesillos símbolos de la abundancia) risueños y pintorescos [...]. (DEL PRADO, 1973, p. 3)

Portanto, no caso de Marina Núñez del Prado, o diálogo entre elementos culturais indígenas e criação artística não se deu apenas no campo da produção escultórica. Como foi esmiuçado anteriormente acerca da fotografia da Puerta del sol, em Tiwanaku [Figura 3], a artista optou por mesclar, em sua autobiografia, imagens provenientes de sua esfera íntima e pessoal com elementos simbólicos que foram sendo incorporados ao longo de sua vida. Existem outras situações em que essa fusão de

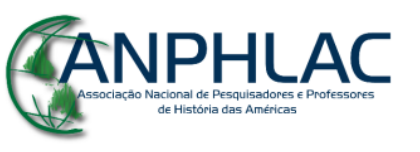

Revista Eletrônica da ANPHLAC, ISSN 1679-1061, №. 24, p. 155-188, Jan./Jun., 2018.

http://revista.anphlac.org.br 
elementos merece ser destacada. Na Figura 6, a artista aparece esculpindo a obra Danza de Cóndores, em seu ateliê na cidade de Buenos Aires. É muito provável que a imagem tenha sido cuidadosamente pensada para destacar a artista no momento de execução de seu ofício de escultora. Contudo, existe outro elemento que merece ser sublinhado: a artista veste um colete com estampas e padrões das tapeçarias tradicionais indígenas. A escolha de sua vestimenta para uma sessão de fotografias não pode ser lida como algo aleatório, e sim a partir da intenção de destacar seu vínculo com as tradições indígenas de sua região, justamente num momento em que se encontrava em outro país, na Argentina.

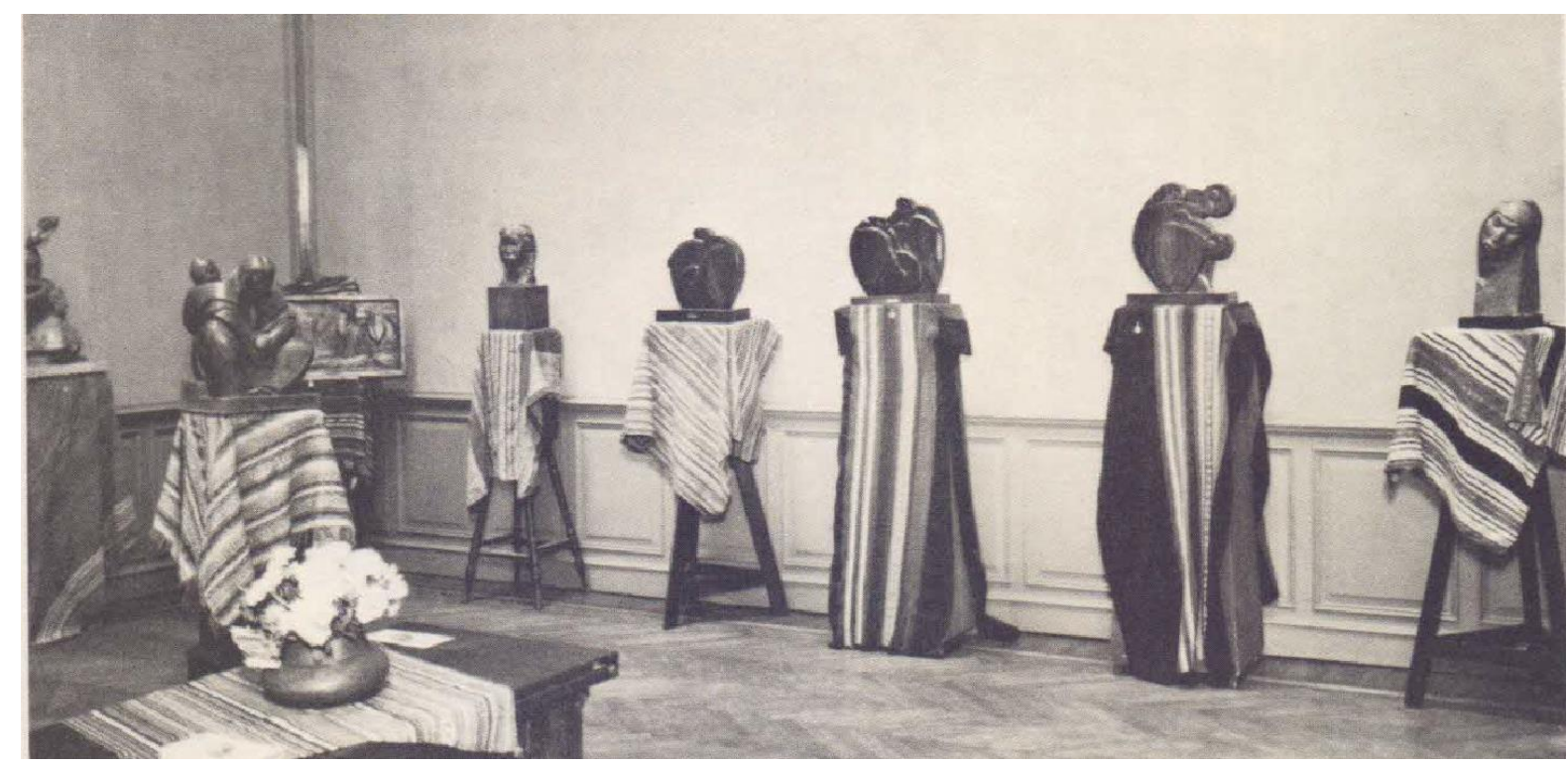

Figura 7. "Mi primera exposición en Buenos Aires, Argentina; Galería Witcomb, 1936”. Foto: Reproduzida no livro Eternidad en los Andes. Santiago, Editorial Lord Cochrane, 1973.

Finalmente, em Mi primera exposición en Buenos Aires (...) [Figura 7], observase o espaço da exposição realizada pela artista na capital argentina. Para além das esculturas selecionadas, outro elemento de destaque são as tapeçarias tipicamente andinas sobre as quais as obras estão colocadas. Em termos visuais, estabelece-se um diálogo interessante entre esses dois elementos - obras e tecidos - pois ao mesmo tempo em que a artista utiliza esses tecidos como elementos para compor o espaço expositivo e "encenar o típico", suas esculturas, ainda que buscando a representação do "tradicional indígena", são a própria manifestação do moderno, sobretudo em sua expressão formal, despojada de um rigor mais acadêmico. Desta maneira, a artista consegue estabelecer

\section{GANPHLAC}

Revista Eletrônica da ANPHLAC, ISSN 1679-1061, №. 24, p. 155-188, Jan./Jun., 2018.

http://revista.anphlac.org.br 
um diálogo entre o típico, representado pelos tecidos, e o moderno, representado pelas próprias obras. Esta associação demonstra a atenção de Marina Núñez del Prado ao próprio programa das vanguardas, de tensionamento entre os polos do tradicional e regional com os do cosmopolita e urbano. Sobre esse conflito, Jorge Schwartz, em seu célebre Vanguardas Latino-Americanas: Polêmicas, manifestos e textos críticos, afirma que:

O conflito entre "nacionalismo" e "cosmopolitismo" talvez seja a polêmica cultural mais constante e complexa do continente latino-americano. Acentuada ainda mais pelo fato de os intelectuais e artistas da região cobrarem maior consciência de sua alteridade em relação aos povos que os colonizaram, emergindo daí uma necessidade imperiosa de afirmar suas especificidades. [...] Como exprimir o nacional, sem resvalar nas limitações empobrecedoras da "cor local"? (SCHWARTZ, 1995, p. 33)

Outro elemento que merece ser analisado é o local de destaque onde foram exibidas as obras. A Galeria Witcomb, localizada no coração de Buenos Aires, foi um centro fundamental na expansão e difusão da arte moderna. Em 1924, o artista Emilio Pettoruci, logo após seu retorno à Argentina, exibiu 86 obras nesta galeria em uma exposição considerada a precursora da arte moderna no país. No mesmo ano, outros artistas, como Xul Solar, também expuseram suas obras nessa galeria. Contudo, entre 1924 e 1936, ano da exposição de Marina Núñez del Prado, o cenário artístico havia se modificado consideravelmente, indicando uma aproximação da arte aos temas da política e a retomada da figuração e do tema ${ }^{9}$, deixados em segundo plano nos anos anteriores em decorrência do predomínio de tendências mais experimentais. Para Jorge Schwartz, "a consolidação do fascismo e a eclosão da Guerra Civil Espanhola, em 1936, levam os artistas e a intelectualidade latino-americana a se questionar sobre o sentido e o compromisso ideológico na arte" (SCHWARTZ, 1995, p. 33) que, dessa forma, passa a se vincular de modo mais evidente com reflexões de cunho social e político.

Para finalizar a reflexão, o trecho seguinte, retirado da autobiografia da artista, destaca a forma pela qual a incorporação das vestimentas tradicionais indígenas no cotidiano de Marina Núñez del Prado contribuiu com sua aceitação nos circuitos

\footnotetext{
9 Em diálogo com a temática indigenista das obras da artista na Galería Witcomb, esse também foi o ano de produção do mural Mercado Colla o Mercado del altiplano, pelo artista argentino Antonio Berni, de fortes traços indigenistas, adquirido pela Fundación Constantini, no ano de 2012. Disponível em: http://www.malba.org.ar/coleccion-online/alfabetico/B/?idobra=2415 Acesso em: 16 de Março de 2017.
}

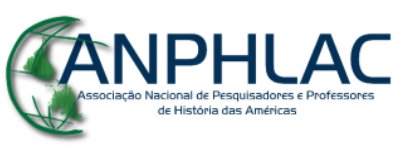

Revista Eletrônica da ANPHLAC, ISSN 1679-1061, №. 24, p. 155-188, Jan./Jun., 2018.

http://revista.anphlac.org.br 
artísticos da cidade de Nova York na década de 1940. Depois de estudar na Art Students League, já com um ateliê montado e produzindo ativamente, a artista passou a buscar uma galeria que a representasse, assim como espaços que se dispusessem a expor seus trabalhos. Porém, essa busca se apresentou muito mais difícil do que o imaginado, e a artista relata que depois de "inumeráveis entrevistas solicitando uma galeria me dei conta de que não era tão fácil. Era preciso adquirir renome, não era suficiente nem válido ter uma obra qualificada, era urgente ter um 'cartão'. Além disso, preferiam os artistas europeus" (DEL PRADO, 1973, p. 58). Frente estas dificuldades, ela relata a maneira pela qual conseguiu romper essas barreiras:

\begin{abstract}
La inauguración de Arte Indio Americano en el Museo de Arte Moderno era por la noche y, además, de gran gala. Esta vez, tenía que hacer algo especial, tenía que llamar la atención de alguna manera. Súbitamente se me ocurrió vestirme de indígena boliviana, en la forma más espectacular posible. Me puse una hermosa chaqueta encarnada de terciopelo profusamente bordada con abalorios y mostacillas y una larga pollera de tejido vernáculo, me adorné con grandes aretes y topos de plata y dejé caer por todas las espaldas mis largas trenzas. Mi presencia fue todo un éxito, desde la entrada en esas salas por las que crucé con paso firme y rítmico como cuadraba a una princesa india. Pronto se me acercaron personas para admirar mi atuendo y preguntarme quién era yo y de dónde venía con ese traje tan exótico; mi hermana Nilda, que me seguía vestida a la europea, respondía: “- Es una Princesa India de Bolivia. Es la escultora Marina Núñez del Prado". Los fotógrafos se agolparon a mi alrededor y las señoras exclamaban: "- Que interesante!" y alguien me presentó a los directores del Museo Moderno, del Metropolitano, del Museo de San Francisco, a Directores de Galerías y de la Unión Panamericana y a otras personalidades del mundo del arte en los Estados Unidos. (DEL PRADO, 1973, p. 59)
\end{abstract}

Esse trecho elucida o lugar comumente reservado aos artistas latino-americanos nos circuitos internacionais, especialmente na Europa e nos Estados Unidos. Ainda que Marina Núñez del Prado fosse, eventualmente, fotografada com roupas que traziam elementos indígenas, ela nunca deixou de se vestir a partir dos padrões europeus e ocidentais. Contudo, teria sido a partir da incorporação desses trajes e de elementos reconhecidos como indígenas e andinos em seu vestuário que a artista teria conseguido se destacar, chamando a atenção para sua produção artística ${ }^{10}$. Ela teria sido aceita, portanto, por se diferenciar daquilo que se esperava de um artista proveniente dos Estados Unidos ou da Europa, aproximando-se de uma imagem idealizada da região

10 Marina viajou para os Estados Unidos em companhia de sua irmã Nilda que, naquele momento, atuava como dançarina e coreógrafa de espetáculos de folclore boliviano e andino. Para a viagem, Nilda levou diversos trajes consigo, dentre os quais, o traje utilizado por Marina na vernissage descrita acima.

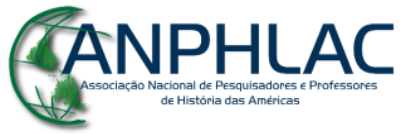

Revista Eletrônica da ANPHLAC, ISSN 1679-1061, №. 24, p. 155-188, Jan./Jun., 2018.

http://revista.anphlac.org.br 
andina, calcada no folclórico e no exótico.

\section{Considerações finais}

Em 1954, quatro anos após seu retorno dos Estados Unidos, Marina Núñez del Prado abriu a casa de sua família, em La Paz, para uma exposição permanente de suas obras. Juntamente com suas esculturas e desenhos, foram expostas peças de orfebrería e pinturas de sua irmã Nilda, assim como a coleção particular da família, composta por obras de arte colonial, republicana, moderna e popular. Paulatinamente, a casa tornou-se um espaço importante no cenário cultural da cidade, recebendo, para além do público em geral, críticos de arte, intelectuais e políticos. A partir de 1969, numa decisão compartilhada entre a artista e Nilda, iniciaram-se os processos para transformar a casa e o acervo particular da família em uma casa-museu gerida por uma fundação.

Não foram encontradas fontes que esclarecessem como a artista decidiu, por fim, escrever suas memórias e publicá-las em formato de livro. Ainda assim, é muito provável que a organização do acervo da casa de La Paz para que fosse aberta ao público tenha contribuído com o processo de construção de sua "memória artística". Ao longo desses anos, Núñez del Prado elaborou uma série de álbuns nos quais apresentava não apenas um inventário da futura casa-museu de La Paz, mas também reproduções em fotografia de grande parte de sua produção - organizada por datas, nomes - assim como centenas de fotografias de passagens importantes de sua vida. Em grande medida, tanto o texto quanto as imagens selecionadas para compor a autobiografia reproduzem esta compilação de informações que a artista já havia organizado previamente.

Atualmente, a obra de Marina Núñez del Prado é celebrada na Bolívia como fundamental para o desenvolvimento da linguagem escultórica no século XX. Não é possível averiguar com exatidão até que ponto seu "trabalho" de memória, nas palavras de Ecléa Bosi (2009, p. 39), contribuiu para este processo. Porém, grande parte da documentação que "exalta" sua atuação data dos anos 1980 em diante. De modo geral, são repercussões na mídia impressa e na intelectualidade acerca da publicação de sua autobiografia em 1973 e da abertura de sua casa-museu em La Paz em 1984. Ao reiterar a ausência de textos autobiográficos da intelectualidade boliviana, Jorge Siles Salinas também indica o quanto as memórias de Núñez del Prado podem ter repercutido no

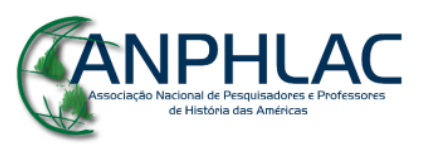


cenário nacional. Nesse sentido, ao se aventurar pelo campo da escrita, é possível que Marina Núñez del Prado tenha conseguido, simultaneamente, firmar-se como uma artista cuja obra deveria ser lembrada.

\section{Referência Bibliográficas}

\section{Obras completas}

BAO, Ricardo Melgar. El movimiento obrero latinoamericano I - Historia de una clase subalterna. México D.F.: Alianza Editorial Mexicana, 1990.

BOSI, Ecléa. Memória e sociedade - Lembranças de velhos, $15^{\text {a }}$ edição. São Paulo: Companhia das Letras, 2009.

DEL PRADO, Marina Núñez. Eternidad en los Andes. Santiago: Lord Cochrane, 1973.

FRANCO, Stella Maris Scatena. Peregrinas de outrora: Viajantes latino-americanas no século XIX. Florianópolis: Editora Mulheres, 2008.

FRANCOVICH, Guillermo. Los mitos profundos de Bolivia. La Paz: Editorial Los Amigos del Libro, 1980.

JELINECK, Estelle. Women's Autobiography. Bloomington: Indiana University Press, 1980. Apud WITZLING, Mara R. Voicing our visions - Writings by women's artists. New York: The Women's Press, 1991.

MENDIETA, P. Wilson. Cecilio Guzmán de Rojas, pintor de los andes. In: Cecilio Guzmán de Rojas - Exposición en el centenario de su nacimiento. La Paz: Fundación Cultural del Banco Central de Bolivia, 1999.

PENTIMALLI, Michela (Org.). Bolivia - Los caminos de la escultura. La Paz: Fundación Simón I. Patiño, 2009.

SMITH, Sidonie; WATSON, Julia (Orgs.). DeColonizing the Subject - The politics of gender in Women's Autobiography. Minneapolis: University of Minnesota Press, 1992.

SOARES, Gabriela Pellegrino; COLOMBO, Sylvia. Reforma liberal e lutas camponesas na América Latina: México e Peru nas últimas décadas do século XIX e princípios do XX. São Paulo: Humanitas FFLCH/USP, 1999.

SCHWARTZ, Jorge. Vanguardas latino-americanas - Polêmicas, manifestos e textos críticos. São Paulo: Iluminuras/Edusp/Fapesp, 1995.

VASCONCELLOS, Camilo de Mello. Imagens da Revolução Mexicana - O Museu Nacional de História do México (1940-1982). São Paulo: Alameda, 2007.

\section{GANPHLAC}

Revista Eletrônica da ANPHLAC, ISSN 1679-1061, №. 24, p. 155-188, Jan./Jun., 2018.

http://revista.anphlac.org.br 
WITZLING, Mara R. Voicing our visions - Writings by women's artists. New York: The Women's Press, 1991.

\section{Capítulos de obra}

MAJLUF, Natalia. El indigenismo en México y Perú: Hacia una visión comparativa. In: CURIEl, Gustavo; MELLO, Renato Gonzaléz; HACES, Juana Gutiérrez (Orgs.) Arte, historia e identidad en América: Visiones comparativas. México: Universidad Autónoma de México, Instituto de Investigaciones Estéticas, 1994.

POLAR, Antonio Cornejo. El indigenismo andino. In: PIZARRO, Ana (Org.). América Latina: Palavra, Literatura e Cultura - Volume 2: Emancipação do discurso. Campinas: Unicamp, 1994.

\section{Artigos de revistas}

ARAÚJO, Nara. Verdad, poder y saber: escritura de viajes femenina. Estudos Feministas, v. 16, n. 3, Florianópolis, 2008, p. 1013.

LEITE, Miriam Lifchitz Moreira. Mulheres viajantes no século XIX. Cadernos Pagu, v. 15, p. 129-143, 2000.

\section{Artigos de periódicos (on-line)}

ARTIÈRES, Philippe. Arquivar a própria vida. Revista Estudos Históricos, Rio de Janeiro, v. 11, n. 21, p. 9-34, 1998. Disponível em: http://bibliotecadigital.fgv.br/ojs/ index.php/reh/article/view/2061 Acesso em: 10 Abr. 2017.

BARROS, José D'Assunção. Os tempos da história: do tempo mítico às representações historiográficas do Século XIX. Crítica Histórica, v. 1, n. 2, 2010. Disponível em: http://www.revista.ufal.br/criticahistorica/attachments/article/72/OS\%20TEMPOS\%20 DA\%20HISTORIA.pdf Acesso em: 03 Fev. 2017.

NORA, Pierre. Entre memória e história - A problemática dos lugares. Projeto História, v. 10, p. 7-28, 1993. Disponível em: https://revistas.pucsp.br/index.php/revph /issue/view/851/showToc Acesso em: 11 Jul. 2017.

\section{Outros}

FABRIS, Annateresa. Memórias em imagens. Anais do XXVI Simpósio Nacional de História (ANPUH). São Paulo, Julho de 2011.

\section{GANPHLAC}


IMANÁ, Gil. Marina, escultora de América. La Prensa, La Paz, Fondo Negro, s/p, 2008.

MOTTA, Romilda Costa. Práticas políticas e representações de si: os escritos autobiográficos da mexicana Antonieta Rivas Mercado e da brasileira Patrícia Galvão/Pagu. 2015. Tese (Doutorado em História Social) - Faculdade de Filosofia, Letras e Ciências Humanas, Universidade de São Paulo, São Paulo. Disponível em: http://www.teses.usp.br/teses/disponiveis/8/8138/tde-21082015-192207/pt-br.php Acesso em: 11 Jul. 2017.

PENTIMALLI, Michaela. Marina Núñez del Prado - Dibujos y Bocetos (c. 19301960)... desde el corazón y los Andes. In: Marina Núñez del Prado - Dibujos y Bocetos. La Paz: Fundación Simón I. Patiño, 2007.

SALINAS, Jorge Siles. Marina Núñez del Prado. El diario, La Paz, Suplemento Cultural Ilustrado, s/p, 2 de Março de 1980.

\section{GANPHLAC}

